\title{
Oncoid growth and distribution controlled by sea-level fluctuations and climate (Late Oxfordian, Swiss Jura Mountains)
}

\author{
Stéphanie Védrine • André Strasser · Wolfgang Hug
}

Received: 29 September 2006 / Accepted: 9 May 2007 / Published online: 5 July 2007

(C) Springer-Verlag 2007

\begin{abstract}
Abundant lagoonal oncoids occur in the Late Oxfordian Hauptmumienbank Member of the Swiss Jura Mountains. Four oncoid types are observed in the studied sections and classified according to the oncoid surface morphology, the structure and composition of the cortex, and the texture and fauna of the encasing sediment. Micritedominated oncoids (types 1 and 2) have a smooth surface. Type 1 has a rather homogeneous cortex and occurs in moderate-energy environments. Type 2 presents continuous or discontinuous micritic laminae. It is associated with a low-diversity fauna and occurs in high-energy facies. Bacinella and Lithocodium oncoids (types 3 and 4) display a lobate surface. They are dominated by microencrusters (Bacinella irregularis and Lithocodium aggregatum) and are found in low-energy facies. The stratigraphic and spatial distribution of these oncoid types shows a correlation with the sequence-stratigraphic evolution of the studied interval, and thus with relative sea-level fluctuations. It can be shown that these sea-level fluctuations were controlled by orbital cycles with 100 - and $20-\mathrm{kyr}$ periodicities. At the scale of 100- and 20-kyr sequences, types 1 and 2 oncoids are preferentially found around sequence boundaries and in transgressive deposits, while types 3 and 4 oncoids are preferentially found around maximum floodings and in highstand deposits. This implies that changes of water energy and water depth were direct controlling factors.
\end{abstract}

S. Védrine $(\varangle) \cdot$ A. Strasser

Department of Geosciences, University of Fribourg,

Pérolles, 1700 Fribourg, Switzerland

e-mail: stephanie.vedrine@unifr.ch

W. Hug

Office Cantonal de la Culture, Paléontologie A16,

Rue de la Chaumont 13, 2900 Porrentruy 2, Switzerland
Discrepancies in oncoid distribution point to additional controlling factors. Platform morphology defines the distribution and type of the lagoon where the oncoids flourished. A low accumulation rate is required for oncoid growth. Additionally, humidity changes in the hinterland act on the terrigenous influx, which modifies water transparency and trophic level and thus plays a role in the biotic composition and diversity in the oncoid cortex.

Keywords Oncoids · Carbonate platform - Sequence stratigraphy $\cdot$ Milankovitch cycles $\cdot$ Sea level .

Palaeoenvironments $\cdot$ Palaeoecology

\section{Introduction}

The term "oncoid" (from the Greek onkos, "lump") was coined by Arnold Heim in 1916. He thus described coated grains in Jurassic and Early Cretaceous limestones in the Swiss Helvetic nappes that differed from "ooids" by nonconcentric layers, not only round but also lobate shapes, dense texture with or without inclusions, and in some cases indistinct boundaries. For oncoid genesis, Heim (1916) invoked micro-organisms (bacteria) and speculated if carbonate was precipitated within the bodies of these organisms, if they only stimulated precipitation by their metabolic activity, or if they agglutinated carbonate particles. In the following decades, several authors described and classified oncoids and interpreted their depositional environments (Peryt 1981; Flügel 2004). Peryt (1983) defined them as "a group of algally (red algae excepted), cyanobacterially and bacterially coated grains, which are initiated in marine and freshwater phreatic environments".

In our study, we focus on marine oncoids that formed during the Late Oxfordian on a part of the shallow 
carbonate-dominated platform on the northern margin of the Tethys ocean, which today is represented by the Swiss Jura Mountains. Late Jurassic marine oncoids have already been described and discussed by Dahanayake (1977, 1978, 1983) from the French Jura and by Gygi (1992) and Hug (2003) from the Swiss Jura. In this paper, the different oncoid types occurring abundantly in the Hauptmumienbank ("main mummy bed") Member in the Swiss Jura are examined in order to better constrain the link between oncoid types and palaeoenvironmental and palaeoecological conditions. We present the results of microfacies analysis, describe the stratigraphic and lateral distribution of the different oncoid types, and discuss the main environmental factors controlling oncoid growth and distribution. We thus test if oncoids can be used as palaeoenvironmental proxy.

\section{Stratigraphic, palaeogeographic, and palaeoclimatic framework}

The stratigraphy of the Oxfordian in the Swiss Jura is well established by Gygi and Persoz (1986) and Gygi (1995, 2000a, 2000b). The oncoid-rich Hauptmumienbank Member belongs to the Vellerat Formation (Fig. 1). This lithostratigraphic unit received its name from Ziegler (1956) who was inspired by Steinmann's (1880) comparison of microbially wrapped grains with Egyptian mummies. Laterally, it passes into the Steinebach Member characterized by ooids. Gygi (2000a, 2000b) attributes the Hauptmumienbank Member to the Late Hypselum ammonite subzone, belonging to the Bimammatum zone. In sequence-stratigraphic terms, the Hauptmumienbank and its lateral equivalents correspond to the transgressive deposits of the Ox 6+ sequence (Fig. 1). This sequence has been identified by Hug (2003) as an additional sequence and overlies the Ox 6 sequence of Hardenbol et al. (1998). Cyclostratigraphic analysis suggests that this sequence corresponds to a 400-kyr orbital eccentricity cycle (Hug 2003; Strasser et al. 2000). The Ox 6+ sequence boundary coincides with a maximum regression on the second-order scale (Hardenbol et al. 1998).

In the Late Oxfordian, the area occupied by today's Swiss Jura was part of a complexly structured but generally shallow epicontinental domain (Fig. 2). The maximum of the second-order regression in the early part of the Bimammatum zone caused large areas to emerge. During the following transgression, abundant carbonate production compensated for the general eustatic sea-level rise and forced the Swiss Jura platform to prograde towards the southeast (Gygi and Persoz 1986). Depressions created by differential subsidence (induced by tectonic movements in the Permo-Carbonifereous basement; Allenbach 2001; Hug 2003) acted as traps for siliciclastics (Pittet 1996;
Wetzel et al. 2003). The different facies occurring on this platform have first been documented by Rollier (1898) and were later described in great detail by numerous authors (e.g., P.A. Ziegler 1956, M.A. Ziegler 1962; Pümpin 1965; Bolliger and Burri 1967, 1970; Gygi 1969, 1982, 1986, 1992; Gygi and Persoz 1986). More recently, Pittet (1996) and Hug (2003) investigated, in more detail, facies and depositional sequences of the Vellerat Formation and Dupraz (1999) studied the palaeoecology of Middle-Late Oxfordian coral reefs. The encountered facies and sedimentary structures indicate depositional environments ranging from tidal flats to shallow lagoons, coral patchreefs, and oolitic bars. Coral bioherms concentrated mainly on the platform edge and in open-marine environments, while oncoid-rich lagoons and ooid bars occupied the internal platform.

The study area was situated at a palaeolatitude of $26^{\circ}$ $27^{\circ} \mathrm{N}$ (Dercourt et al. 1993). Climate was warm. Frakes et al. (1992) indicate up to $27^{\circ} \mathrm{C}$ for the Late Oxfordian ocean surface temperatures according to oxygen isotopes measured on planktonic foraminifera and belemnites. Based on $\delta^{18} \mathrm{O}$ analyses of Middle Oxfordian samples from the Swiss Jura platform, Plunkett (1997) also calculated palaeotemperatures of $26-27^{\circ} \mathrm{C}$. In the Middle and Late Oxfordian, abundant rainfall in the hinterland allowed vegetation growth and continental run-off of siliciclastics into the study area (Gygi 1986; Pittet 1996). Associated nutrient input periodically led to eutrophication and to crises of coral reefs (Dupraz and Strasser 1999). Towards the Late Oxfordian (Berrense subzone) and Kimmeridgian, climate became more arid, as indicated by generally less siliciclastics but occurrence of evaporite pseudomorphs (Hug 2003; Rameil 2005). The siliciclastic-dominated Röschenz Member implies humid conditions (Fig. 1). In the overlying Hauptmumienbank Member, kaolinite is abundant but detrital quartz is present only in small quantities (Gygi and Persoz 1986). This may point to a northward shift of the siliciclastic source area and/or to diminishing rainfall in the hinterland. Only the floating clay minerals and organic matter reached the study area, whereas the quartz grains were left behind (Thiry 1982). The source area is not known but supposed to have been situated in the London-Brabant, Rhenish and Bohemian massifs, and/or in the Central Massif (Fig. 2). This general climatic evolution was controlled by highfrequency climate changes related to orbital (Milankovitch) cycles. These not only controlled siliciclastic input through periodically increased rainfall but also periodic evaporite formation (Pittet 1996; Hug 2003). Furthermore, they were responsible for low-amplitude sea-level fluctuations that led to the formation of hierarchically stacked depositional sequences (Strasser et al. 1999, 2000). 


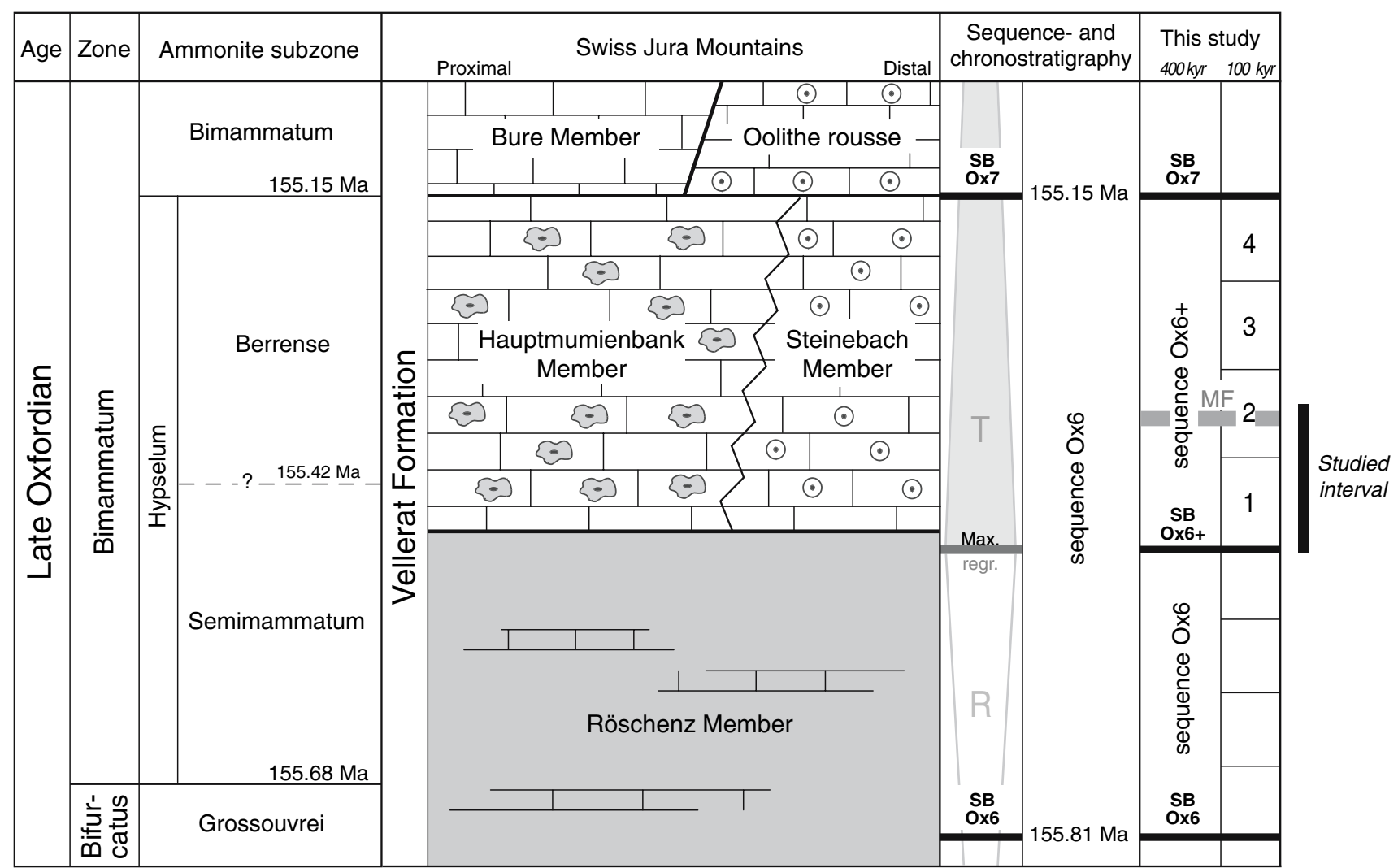

Fig. 1 Lithostratigraphic, biostratigraphic, and sequence-stratigraphic position of the Hauptmumienbank Member on the Swiss Jura platform (after Gygi and Persoz 1986; Gygi 1995, 2000a, 2000b; Hardenbol et al. 1998). The studied interval corresponds to one and a half small-scale (100-kyr) sequence between the transgressive surface of medium-scale (400-kyr) sequence Ox 6+ at the base of the Hauptmumienbank Member and the maximum flooding of sequence Ox 6+. SB Sequence boundary, $M F$ Maximum flooding, $R$ Second-order regressive trend, $T$ Second-order transgressive trend. Ages of ammonite subzone boundaries and of sequence boundaries according to Hardenbol et al. (1998)

\section{Studied sections and methodology}

The studied interval corresponds to the transgressive part of the Ox 6+ sequence (Hug 2003). Six platform sections (Voyeboeuf, Vorbourg, Hautes-Roches, Court, Savagnières, and Pertuis) were logged in detail and densely sampled (Figs. 3, 4, 5). These sections exhibit lagoonal facies: oncoid, ooid, bioclastic, and peloid-rich deposits. Based on field observations, 300 polished sections and thin sections, plus 25 washing residues of marls, facies and microfacies have been analyzed. Analyses of the texture and relative abundance of skeletal and non-skeletal elements (Fig. 4) were performed from thin sections. These informations were then interpreted in terms of palaeoenvironments. Stacking pattern, bed surfaces, and facies were used for sequence and cyclostratigraphic interpretations (Strasser et al. 1999). This helped to correlate the sections and to trace the vertical and lateral evolution of facies types. Figure 6a shows an example of high-resolution sequence-stratigraphic correlations for two elementary sequences. Based on these correlations, platform evolution through time is reconstructed
(Fig. 6b). Based on the dominant facies, the sections are positioned from "proximal" (Voyeboeuf) to "distal" (Savagnières and Pertuis) in Fig. 7. However, because platform morphology changed through time, these attributions can only indicate the general trend.

\section{Facies evolution and depositional sequences}

The evolution of depositional environments through time is reconstructed from high-resolution facies analysis of the six studied sections. Facies evolution and stacking pattern of the beds lead to the definition of depositional sequences of different orders. Elementary sequences are the smallest units, in which one environmental cycle can be recognized (e.g., a deepening then shallowing trend, or an opening then closing of a lagoon as indicated by energy and faunal changes). In most cases, one elementary sequence corresponds to several beds. These elementary sequences stack into bundles (commonly of five elementary sequences) defining small-scale sequences, which again show charac- 


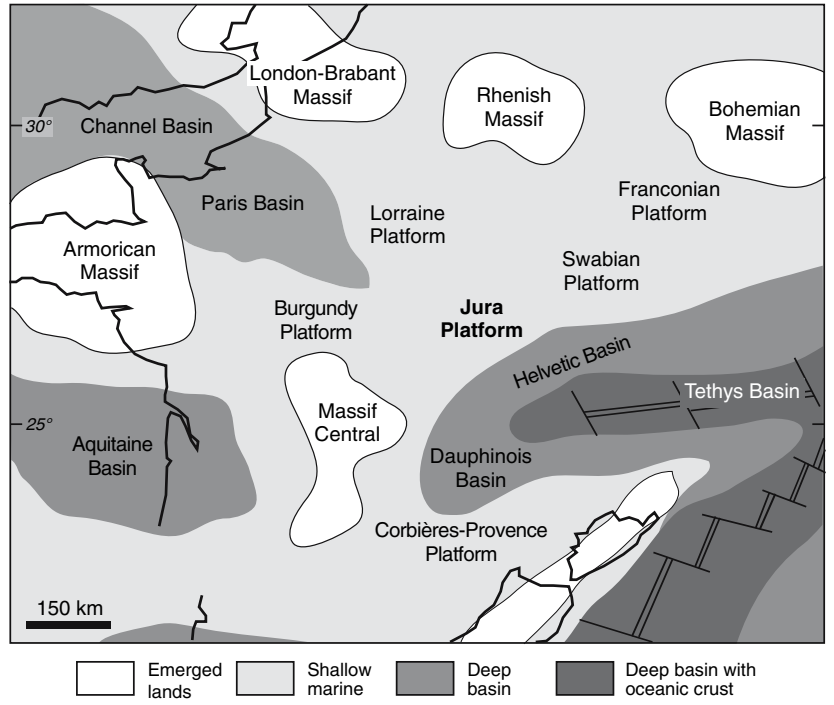

Fig. 2 Late Jurassic palaeogeography of the northern margin of the Tethys ocean, including the Jura platform, the Paris Basin, and the surrounding crystalline massifs (modified from Ziegler 1988; Thierry et al. 2000)

teristic facies evolutions. Four small-scale sequences then group into one medium-scale sequence. Depositional sequences of all scales can be interpreted in terms of sequence stratigraphy (Strasser et al. 1999). Boundaries between sequences correspond to the shallowest or most

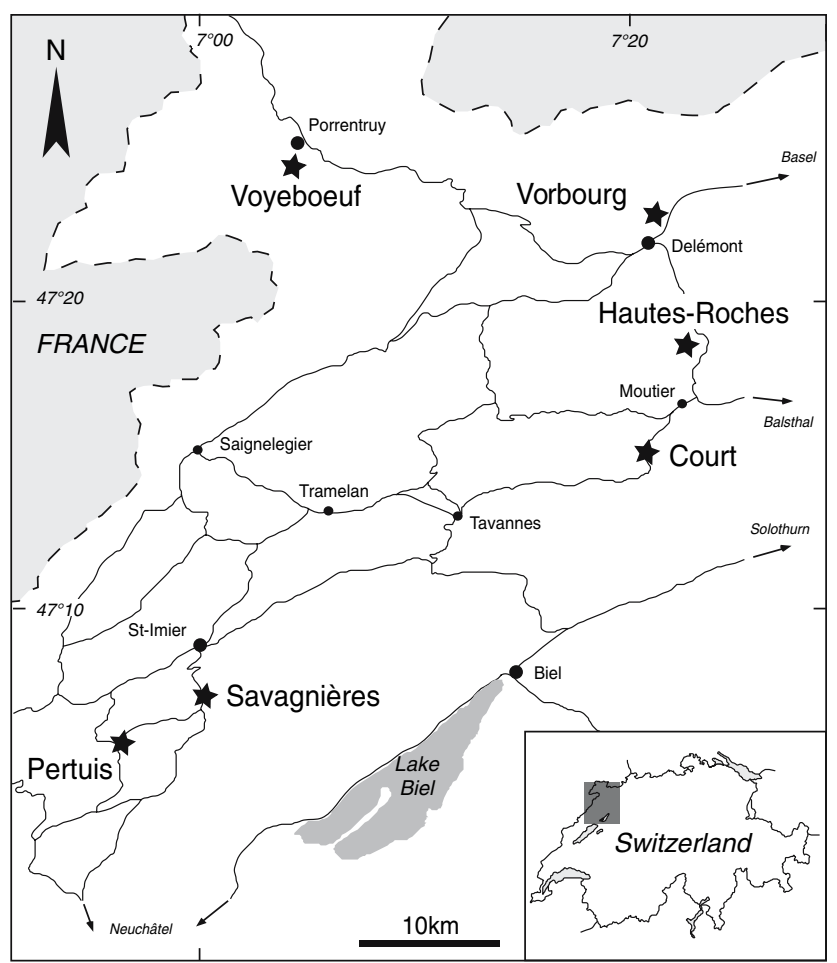

Fig. 3 Geographical position of the six studied sections in the Swiss Jura Mountains

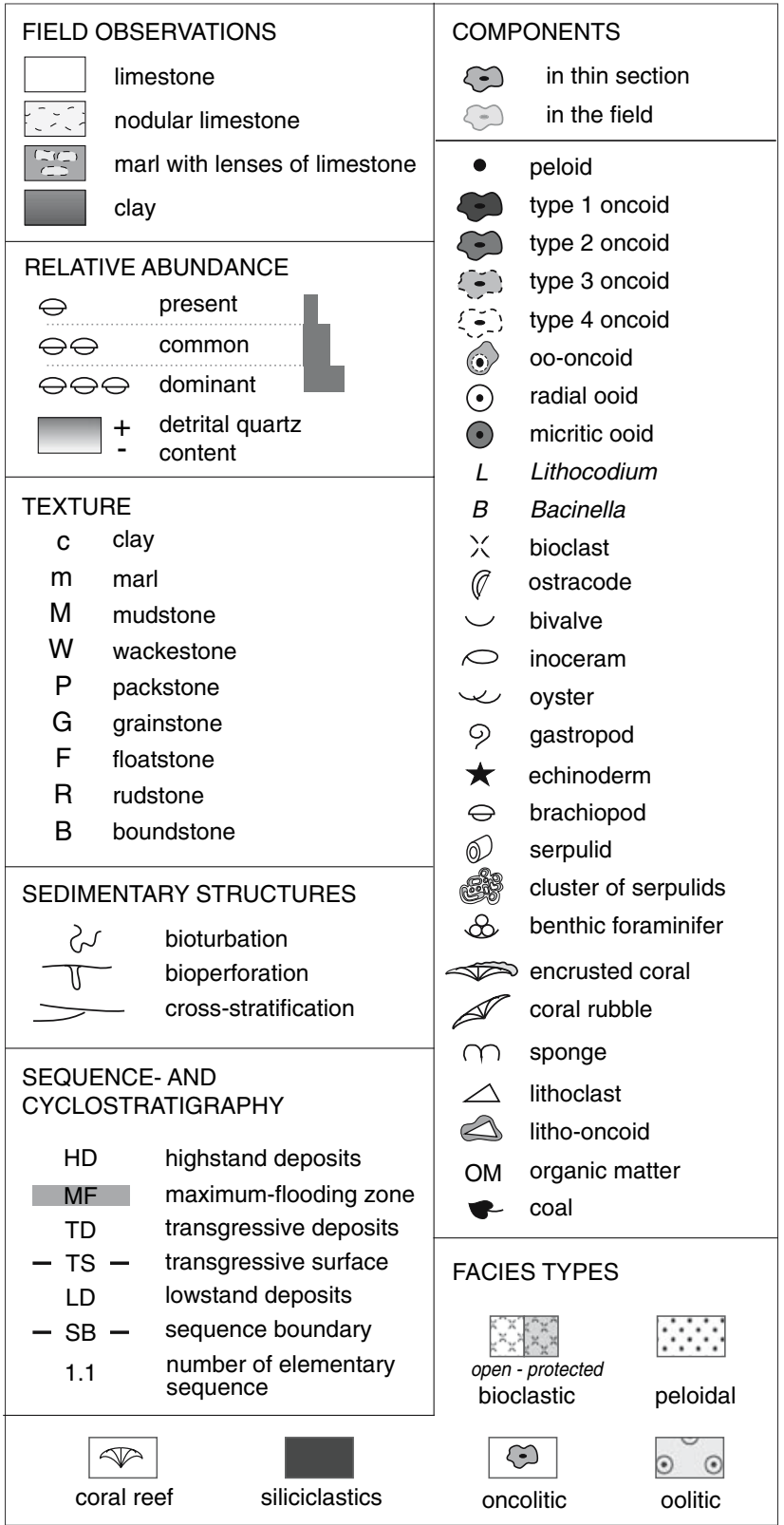

Fig. 4 Legend to sections

protected facies, implying a drop of relative sea level. Rapid deepening or opening of facies is interpreted as a relative sea-level rise, and facies suggesting the relatively deepest water or the most open-marine conditions are attributed to the maximum flooding within the sequences. Once the depositional sequences and their hierarchical stacking are identified for each section, a correlation between the sections is attempted. Within the biostratigraphic framework of Gygi and Persoz (1986) and Gygi (1995), a fairly coherent sequence-stratigraphic correlation can be proposed. On the level of the small- and mediumscale sequences, the sequence boundary and maximumflooding intervals in the Hauptmumienbank Member are 
correlated over the whole study area (Hug 2003). On the level of the elementary sequences, correlation is sometimes difficult because facies evolution does not always display unequivocal deepening-shallowing or opening-closing trends. Furthermore, autocyclic processes partly controlled facies evolution (Strasser 1991).

Based on the absolute ages given by Gradstein et al. (1995), Hardenbol et al. (1998) dated SB Ox 6 at 155.81 Ma and SB Ox 7 at $155.15 \mathrm{Ma}$ (Fig. 1). This implies a time span of 600-700 kyr between these two sequence boundaries. In the corresponding interval, Hug (2003) counted 6-8 small-scale sequences, each composed of five elementary sequences. The same number is found in the other sections that cover this interval (Pittet 1996; Hug 2003; Strasser et al. 2000). This suggests that a small-scale sequence formed within $75-117 \mathrm{kyr}$, and an elementary sequence within $15-23 \mathrm{kyr}$. These values coincide well with those of the first orbital eccentricity cycle (100 kyr) and of the precession cycle (between 18 and $22 \mathrm{kyr}$ in the Oxfordian; Berger et al. 1989). It is implied that these orbital cycles induced climate changes that translated into sealevel fluctuations, which in turn controlled the formation of the observed depositional sequences.

Within this sequence and cyclostratigraphic framework, facies can now be correlated across the whole studied platform. The rapid vertical facies change between the Röschenz Member and the Hauptmumienbank Member corresponds to a major transgressive surface, which is manifest all over the Jura Mountains (Hug 2003). Facies distribution in the Oxfordian of the Swiss Jura is very heterogeneous and displays important lateral changes (Pittet 1996; Jordan 1999; Gsponer 1999; Hug 2003; Samankassou et al. 2003). Also the Hauptmumienbank Member, defined by its richness of oncoids, has a very inhomogeneous and diachronous distribution on the Jura platform (Fig. 7). Rapidly changing sediment thicknesses imply differential subsidence. This feature has also been recognized by Allenbach (2001), who related it to reactivation of ancient tectonic lineaments. Reefs formed on structural highs along the platform margin but could later find themselves in rapidly subsiding areas due to tectonic inversion. Ooid bars not only occurred on the platform margin but also in the platform interior where morphological highs created favorable conditions. Locally, wide channels brought relatively open-marine conditions into more central platform positions, generating high-energy depositional environments. Behind reefs and bars, lagoons were isolated or protected from open-marine influence and from wave or current energy (Fig. 6b; Hug 2003; Strasser and Védrine 2007). Lagoonal facies with oncoids shows a patchy distribution. No systematic relationship with the other facies is recognizable, although the most persistent oncoid lagoons appear to be situated preferentially on the inner platform when compared to ooid bars and coral reefs.

\section{Oncoids}

The oncoids found in the Hauptmumienbank Member display a wide variability in size, shape, and composition. The following criteria have been used for defining types: surface morphology, size, cortex structure and composition, and sedimentological context.

\section{Classification}

Observed oncoid sizes vary between a few millimetres to a few centimetres. The oncoids have a well-defined rounded or irregular shape and smooth, wavy, or lobate contours. The final shape follows in many cases that of the nucleus, although a higher sphericity is obtained. If a nucleus is present, it is of bioclastic or lithoclastic nature and the envelope has a variable thickness. The cortex is characterized by micritic and/or organism-bearing laminations, which are continuous or discontinuous when the oncoid surface was eroded (Figs. 8, 9, 10). The types of oncoids are defined and differentiated by the surface morphology and by the presence, the nature, and the abundance of microencrusters in their cortex. Microfacies analysis of the encasing sediment furnishes the environmental context within which the oncoids were formed. The Hauptmumienbank oncoids are mainly found in wackestones, locally floatstones or rudstones, with bioclasts, ooids, and peloids. Transported micrite-dominated oncoids are also observed in ooid-rich grainstones. Texture, faunal composition, and sedimentary structures suggest a deposition in shallow-water lagoons.

Based on more than 300 thin sections and macroscopic samples from the Hauptmumienbank Member, four types of oncoids are distinguished (Fig. 11). Transitions between types also exist, suggesting a continuum.

Type 1 oncoids have diameters of a few millimetres and correspond to elliptical or spherical particles with relatively smooth contours. The cortex is micritic, homogeneous, and without microencruster inclusions (Fig. 8a, b). This pattern probably results from the trapping of fine-grained sediment on the oncoid surface by microorganisms. Laminations are difficult to distinguish. Type 1 oncoids are preferentially found in peloidal and bioclastic (foraminifera, bivalves, echinoderms) mudstones-wackestones of protected and moderate-energy lagoonal environments. This type of oncoid is relatively rare in the studied interval (Fig. 12).

Type 2 oncoids have diameters of a few millimetres (up to $1 \mathrm{~cm}$ ) and present elliptical shapes with smooth contours. The cortex has irregular and locally truncated micritic laminae, and different growth phases can be distinguished in many cases (Figs. 8c, d, 9). This suggests relatively highenergy conditions with intermittent periods of wave agitation leading to a partial erosion of the cortex. The cortex of the micrite-dominated oncoids presents a relatively low-diversity 

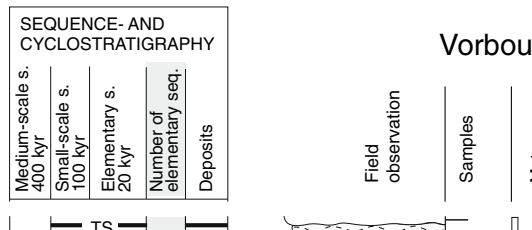

Vorbourg

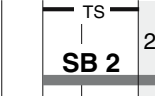

$2.1 \mathrm{LD}$

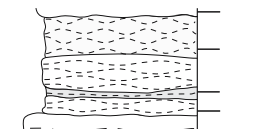

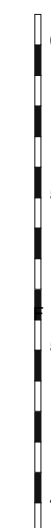
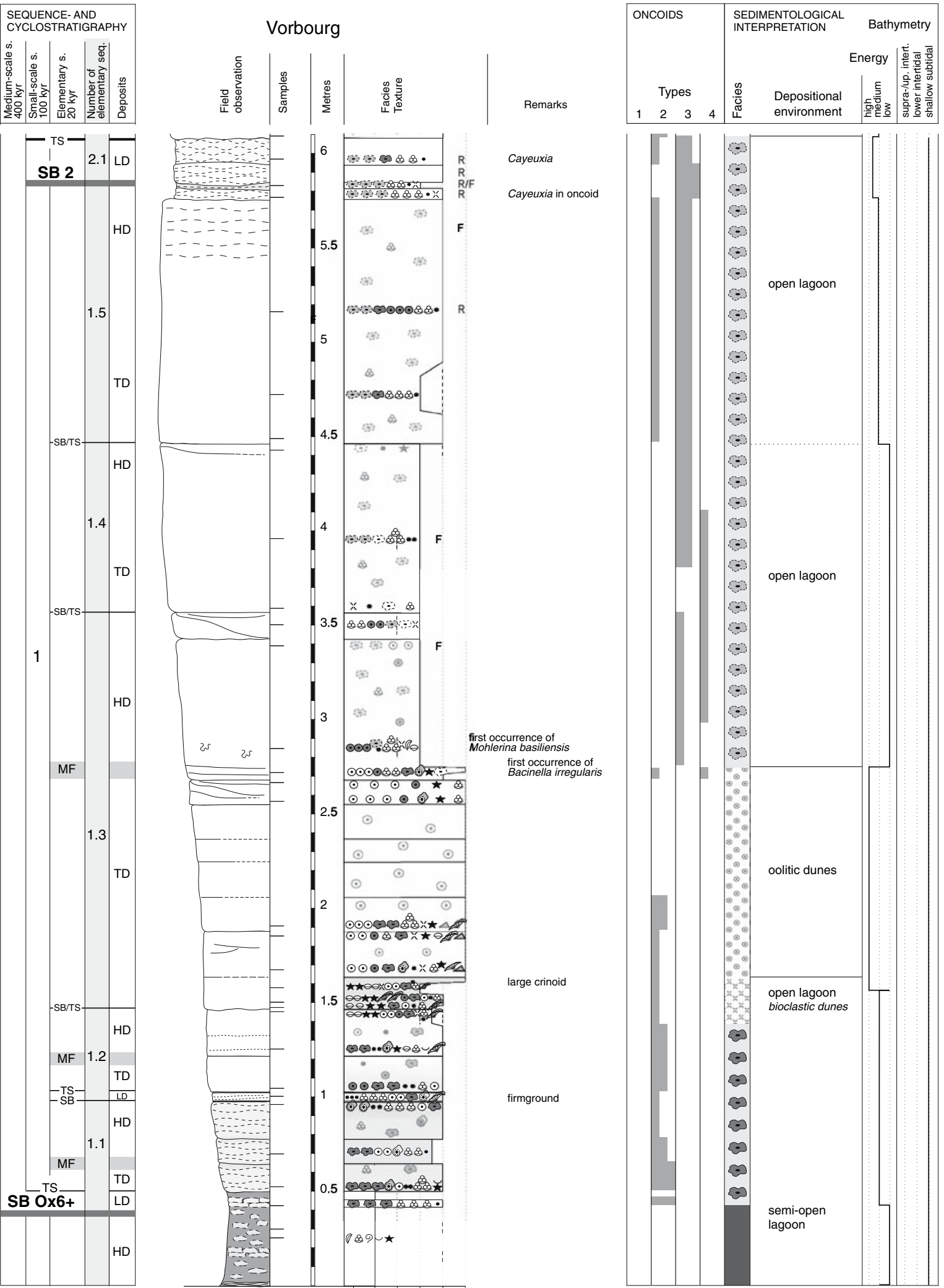

$\left.5\right|_{4} ^{3}$

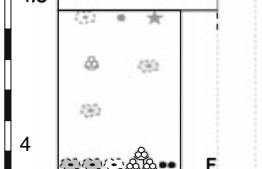

4 Her F

$1 \infty$

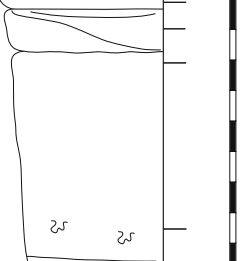

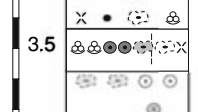

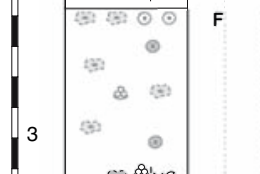

first occurrence of
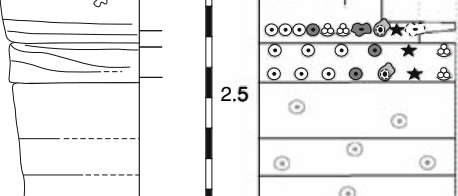

first occurrence of

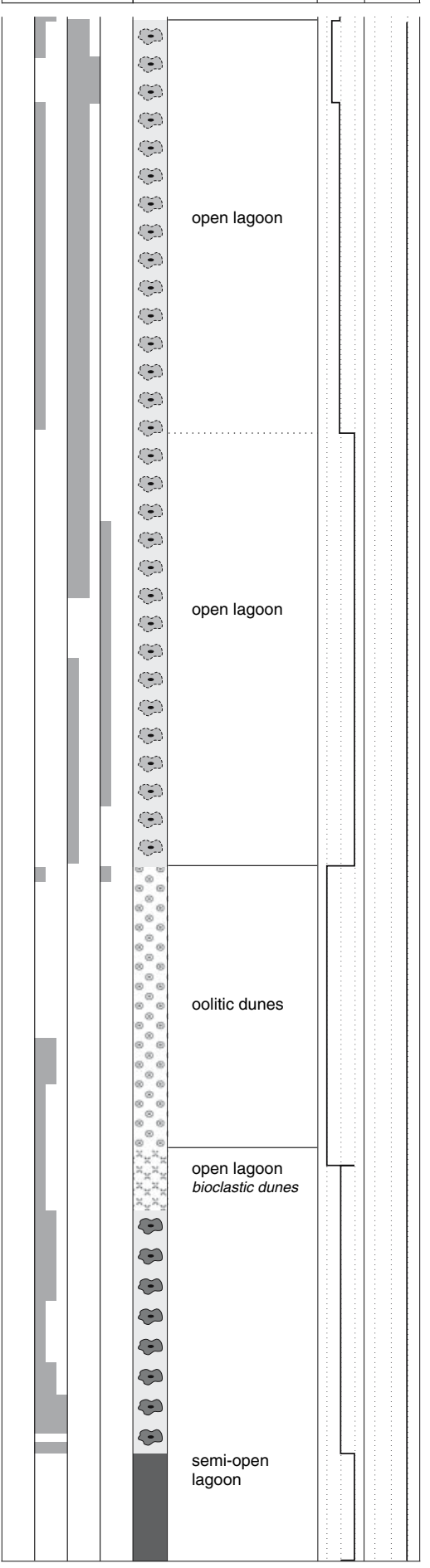

Fig. 5 Detail of the first small-scale sequence of the Vorbourg section, showing the distribution of the four oncoid types, facies types, palaeoenvironmental interpretation, and the sequence-stratigraphic framework. For discussion refer to text. Legend of symbols in Fig. 4 

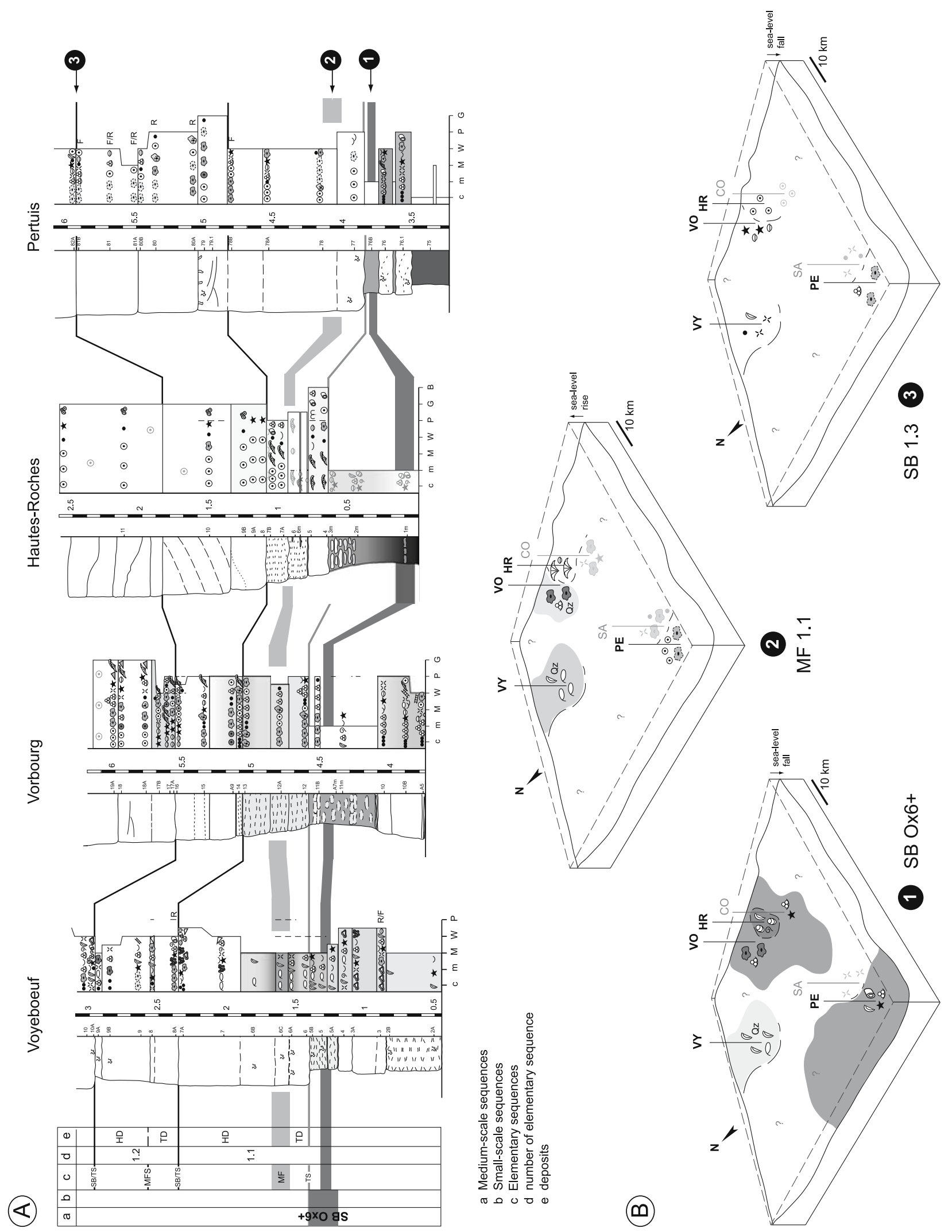

Fig. 6 a Example of high-resolution correlation of Voyeboeuf, Vorbourg, Hautes-Roches, and Pertuis for two elementary sequences. For symbols, refer to Fig. 4. b Schematic sketches showing the facies distribution on the Swiss Jura platform (1 SB Ox 6+; 2 MF 1.1; 3 SB 1.3) 

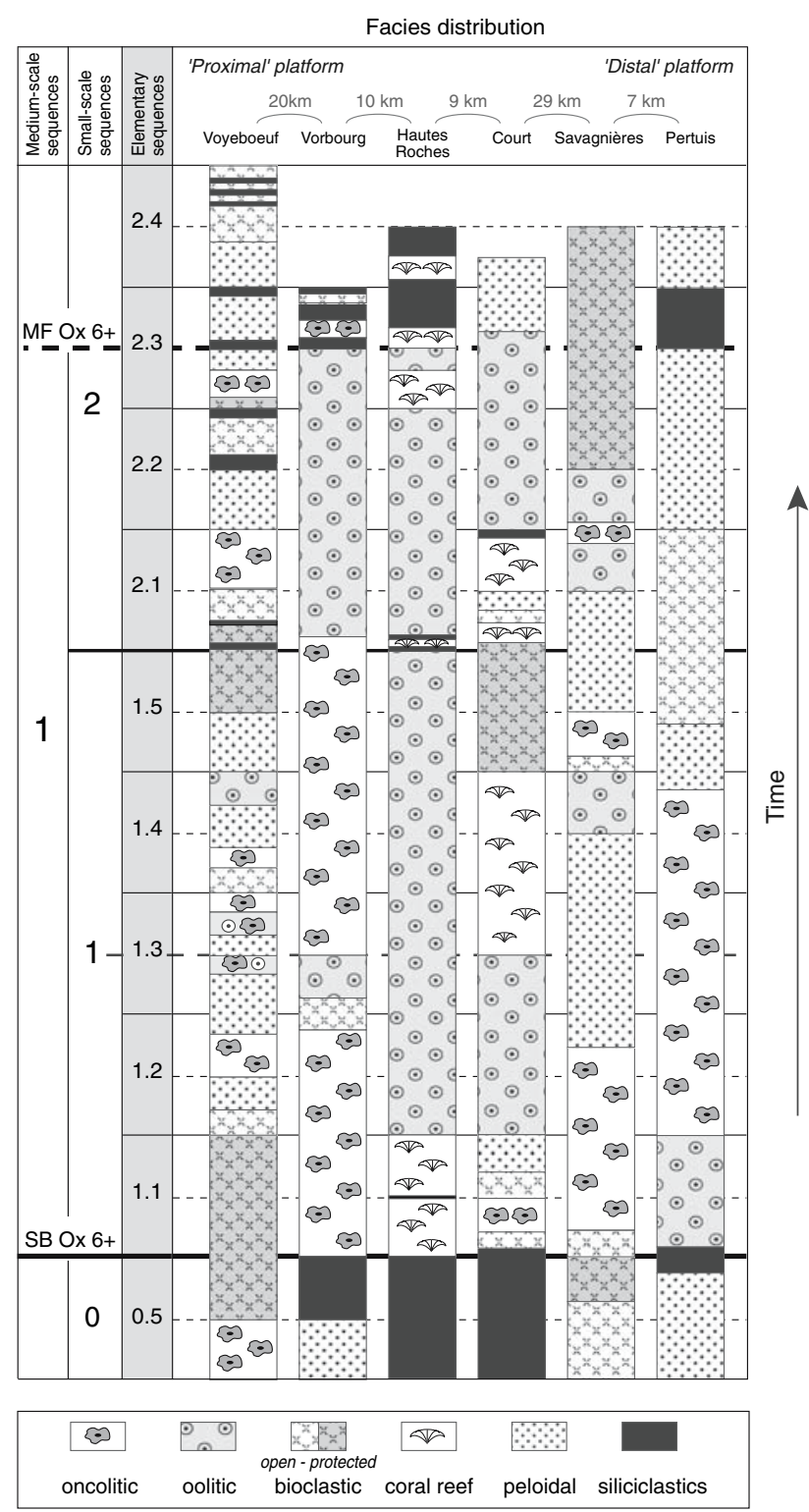

Fig. 7 Distribution of major facies types through time within the studied interval across the Swiss Jura platform. The duration of elementary sequences is considered to be equal ( $20 \mathrm{kyr})$

fauna such as serpulid worms and Bullopora. Occasionally, ooids are incorporated in the cortex (Fig. 9c, d). These oncoids are found in packstones with normal-marine or semi-restricted fauna (brachiopods, oysters, foraminifera, echinoderms, bivalves, serpulids, ostracodes) and also in marls. Type 2 oncoids are common in all studied sections (Fig. 12).

Type 3 oncoids have diameters of a few millimetres to a few centimetres (up to $5 \mathrm{~cm}$ ) and sub-elliptical shapes with wavy contours. The cortex is made of alternating organismbearing and thin micritic laminations (Fig. 10). The organism-bearing laminations are formed by two microencrusters: Bacinella irregularis (Radoicic 1959; Fig. 10d) and
Lithocodium aggregatum (Elliott 1956; Fig. 10e). Bacinella irregularis is an enigmatic microencruster with an irregular micritic meshwork and interspaces filled with calcite spar. This is assumed to represent a cyanobacterial structure (e.g., Schmid 1996; Dupraz 1999; Shiraishi and Kano 2004). Lithocodium, originally interpreted as a codiacean alga by Elliott (1956), is characterized by inner cavities and an aggregated outer wall with numerous alveoli (complex wall structure) probably containing symbiotic and photosynthetic algae (Schmid and Leinfelder 1996). These authors thus attributed it to a loftusiacean foraminifer with an encrusting life habit. Recently, Cherchi and Schroeder (2006) interpreted Lithocodium as colonies of calcified cyanobacteria because of the absence of apertures connecting neighboring cavities, and because of the very irregular form and arrangement of these hollows. These BacinellaLithocodium oncoids can be compared to the porostromate oncoids of Peryt (1981) because of the presence of cyanobacteria in their cortex. The alternation of micrite laminae and organism-bearing laminae suggests calm periods during which Bacinella-Lithocodium could grow and more agitated periods when micrite laminae are formed by the rolling on the lagoon floor. Type 3 oncoids are preferentially found in wackestones with normal-marine fauna (brachiopods, oysters, foraminifera, echinoderms, bivalves) indicating relatively low-energy conditions. The BacinellaLithocodium association characterizes lagoonal environments with oligotrophic conditions, low accumulation rate, clear, oxygenated, shallow, and normal-marine waters (e.g., Leinfelder et al. 1993; Dupraz and Strasser 1999; Immenhauser et al. 2005). Dupraz and Strasser (1999), who examined the encrustations of Oxfordian coral reefs in the Jura, correlated the Bacinella-Lithocodium association with episodes of relatively high coral diversity. Bacinella and Lithocodium have also been identified in the microbial crusts associated with coral and sponge reefs of the Late Jurassic (e.g., Helm and Schülke 1998; Dupraz and Strasser 1999; Schmid and Leinfelder 1996; Olivier et al. 2004; Shiraishi and Kano 2004). This may suggest that palaeoecological conditions for Bacinella-Lithocodium bearing oncoids were analogous. The presence of the benthic foraminifer Mohlerina basiliensis (Mohler 1938; Schlagintweit and Ebli 1999; Schlagintweit et al. 2005), preferentially in wackestones with type 3 and/or 4 oncoids, suggests that oncoids and benthic foraminifera were, at least partly, controlled by similar environmental parameters.

Type 4 oncoids have diameters of a few millimetres to several centimetres (up to $10 \mathrm{~cm}$ ) and display irregular shapes with lobate contours. Exclusively composed of Bacinella and/or Lithocodium meshwork, they have no nucleus or laminations (Fig. 10f). Type 4 oncoids are found in bioclastic wackestones, commonly associated with type 3 oncoids. Low-energy conditions with no or only rare 

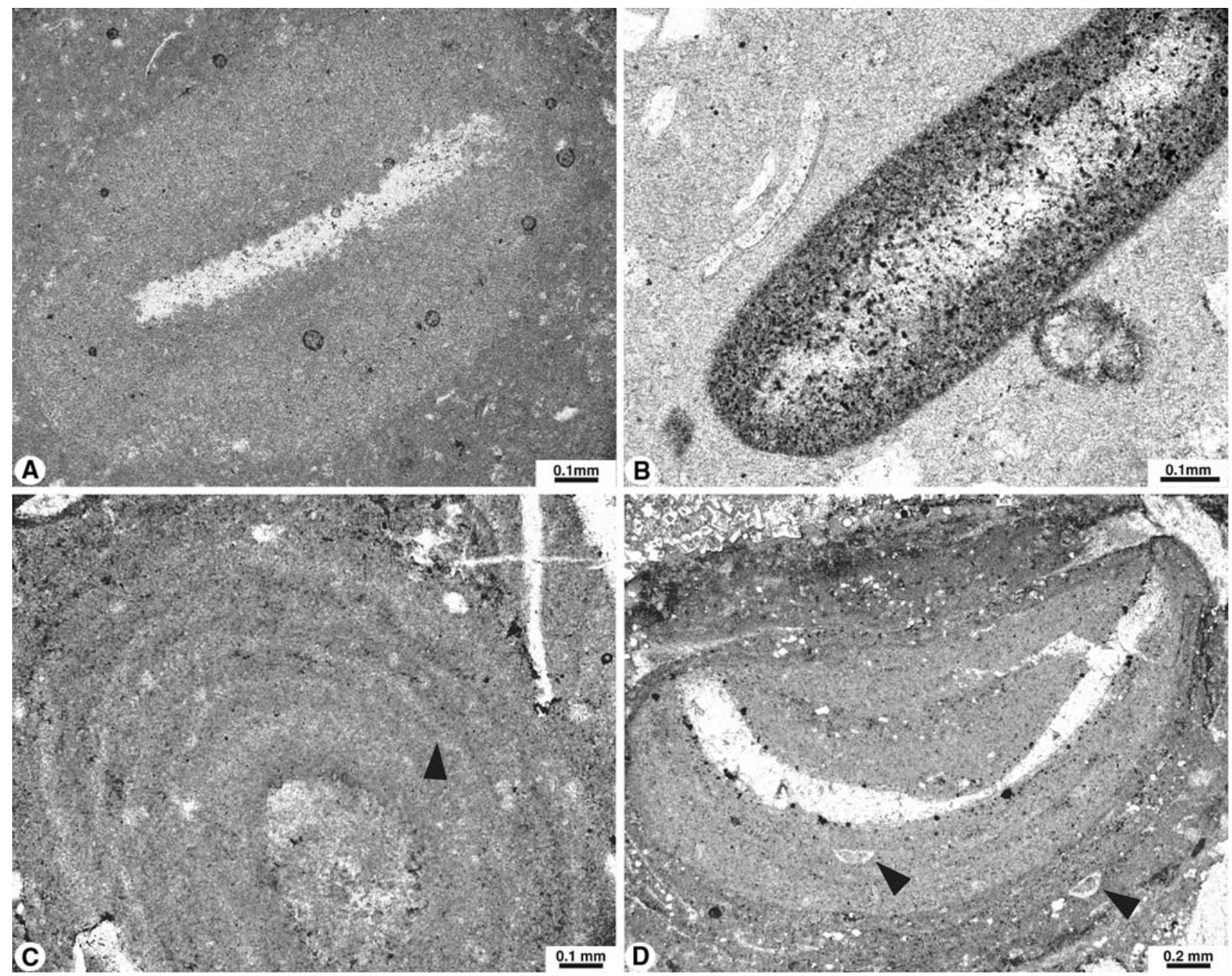

Fig. 8 a Type 1 oncoid with echinoderm fragment as nucleus and homogeneous, micritic cortex with barely visible laminations, found in a bioclastic wackestone. Savagnières section, thin section Sa-32C. b Type 1 oncoid with bioclastic nucleus and thin micritic cortex without laminations. Court section, thin section BPCo-55. Black dots are

pyrite. c Elliptical type 2 oncoid with a micritic, laminated cortex and some sparry patches (dissolved organisms?) Truncated laminae appear locally (arrow). Pertuis section, thin section Pe-80A. d Type 2 oncoid enclosing the foraminifer Bullopora sp. (arrows). Vorbourg section, thin section Vo-K

agitation are suggested. Locally, type 4 oncoids develop into carpet-like structures and build-ups of Bacinella (e.g., Hug 2003; Immenhauser et al. 2005).

\section{Oncoid distribution}

From the high-resolution sequence-stratigraphic framework, a time-space diagram illustrating the distribution of oncoid types is synthesized (Fig. 12). A proximal-distal trend is revealed by the greater abundance of type 3 oncoids in the "distal" platform sections (Pertuis and Savagnières); while in the "proximal" section (Voyeboeuf) types 2 and 1 oncoids predominate. Hautes-Roches and Court, which are mainly composed of ooid-rich deposits and patch-reefs, almost exclusively present type 2 oncoids. The different

oncoid types coexist, except types 1 and 4 that occur in very different environmental settings concerning mainly water energy (Fig. 11). Regardless of these general trends, it appears that local conditions (e.g., clay input) played an important role in oncoid development (Fig. 7). Migrating ooid bars locally interrupted the oncoid sedimentation.

A specific evolution of oncoid types is occasionally observed within small-scale and elementary depositional sequences. Oncoids are generally more abundant in the first small-scale sequence than in the second one (Fig. 7). Based on the high-resolution sequence-stratigraphic framework, a detailed description of the oncoid type distribution is given for the Vorbourg section (Fig. 5). The lowstand and transgressive deposits of the first small-scale sequence contain abundant type 2 oncoids (Figs. 5, 7). Migration of ooid bars locally interrupts oncoid deposits in the upper part of the 

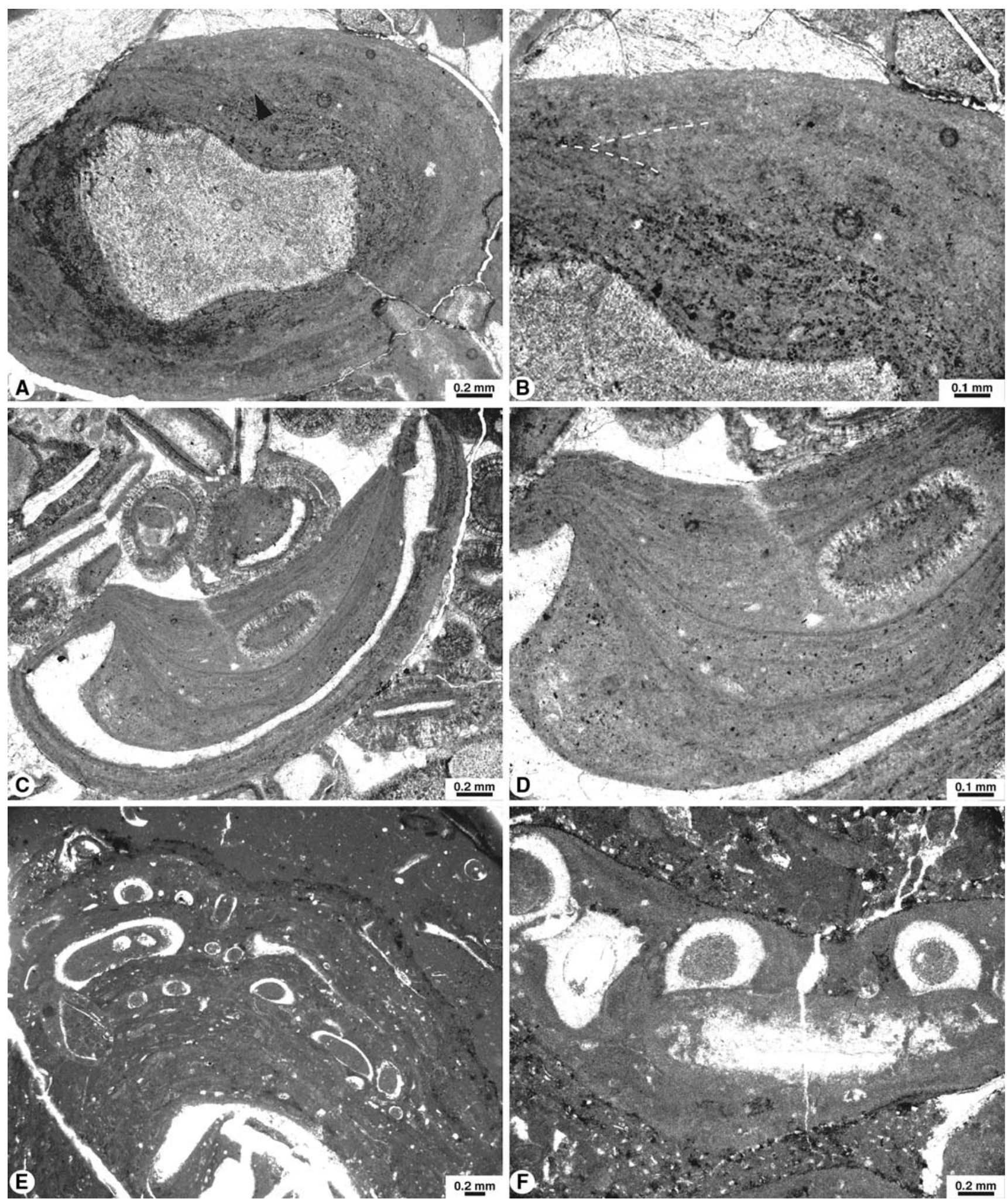

(D)
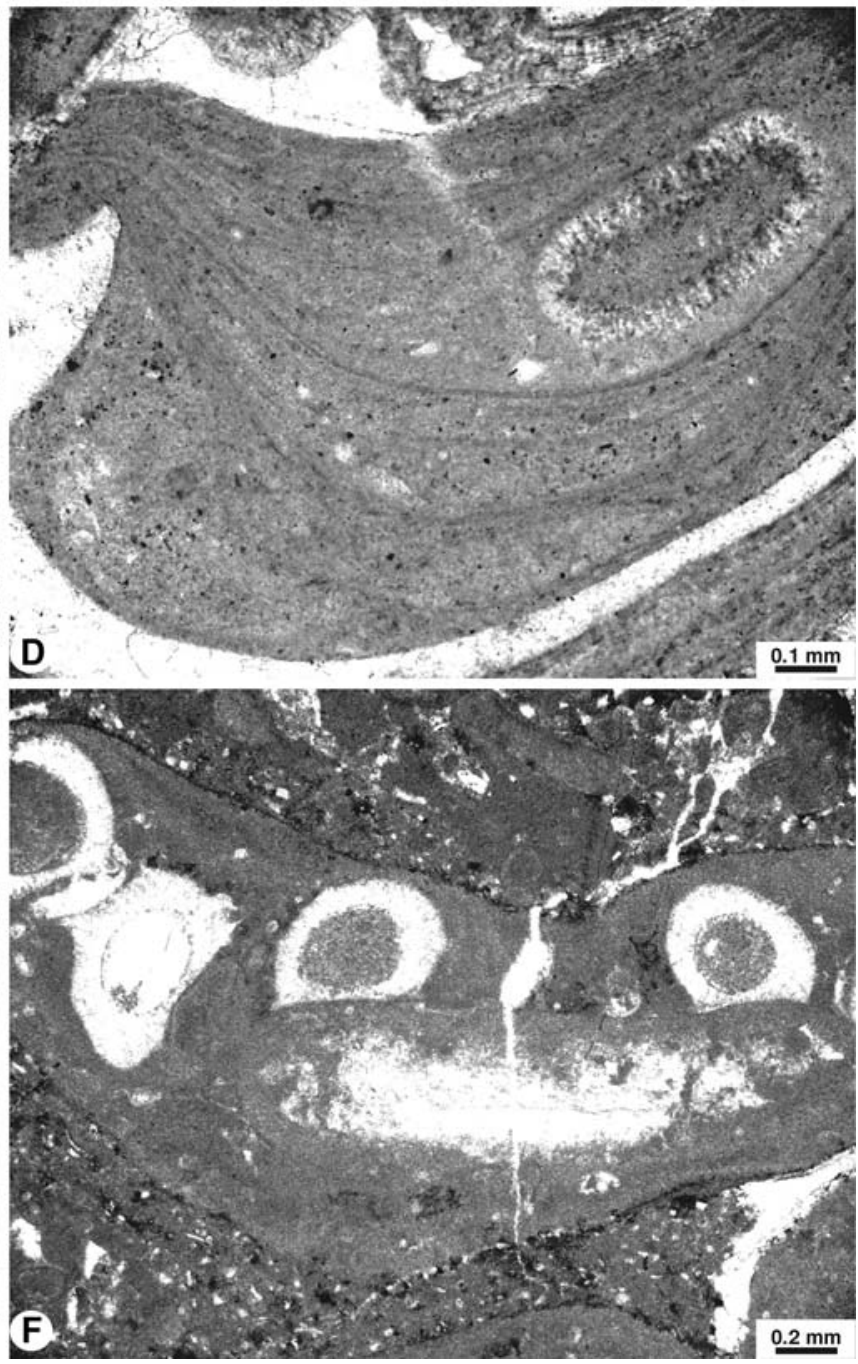

Fig. 9 Type 2 oncoids. a Elliptical oncoid with a large echinoderm fragment as nucleus and smooth contours. Micritic laminations of a first growth phase are onlapped by those of a second phase (arrow). Court section, thin section BPCo-81. b Detail of (a) showing the onlapping micritic laminae. Court section, thin section BPCo-81. c Elongate type 2 oncoid. In a first growth phase the laminae followed the shape of the nucleus. A radial ooid was then trapped, and in a second growth phase the cortex strived

towards a more and more rounded shape. Court section, thin section BPCo-81. d Detail of (c) showing the trapped ooid. Court section, thin section BPCo-81. e Type 2 oncoid with a bioclastic nucleus and irregular micritic laminae. Serpulid worms encrusted and then were incorporated into the cortex. Voyeboeuf section, thin section Vy-8A. f Micritic oncoid formed by several phases of growth. Large serpulid worms encrusted at different growth stages. Voyeboeuf section, thin section Vy-12Cs 

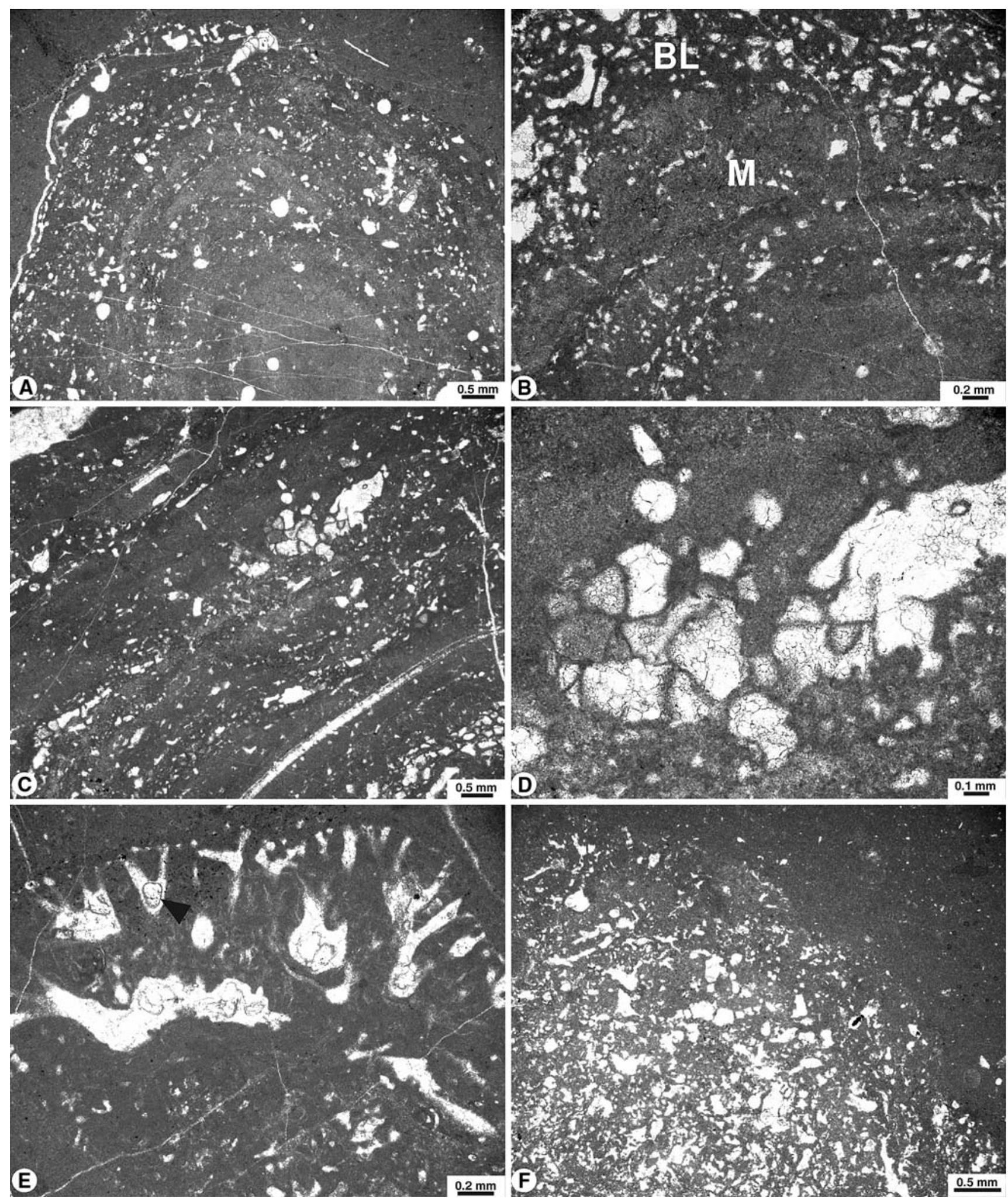

Fig. 10 Types 3 and 4 oncoids. a Type 3 oncoid with a cortex composed of irregular organism-bearing Bacinella-Lithocodium laminations and thinner micritic laminations. The contour is lobate. Pertuis section, thin section Pe-81A. b Detail of type 3 oncoid with BacinellaLithocodium meshwork BL and micritic laminations M. Pertuis section, thin section Pe-82A. c Detail of a type 3 oncoid cortex. Pertuis section, thin section Pe-82A. d Detail of the vesicular structure of

Bacinella irregularis. Pertuis section, thin section Pe-82A. e Lithocodium aggregatum with cavities colonized by cryptobiontic foraminifera (probably Troglotella incrustans; arrow) and a complex wall structure. Pertuis section, thin section Pe-84A. f Type 4 oncoid with lobate and diffuse contours, entirely composed of Bacinella irregularis. Voyeboeuf section, thin section Vy-20 


\begin{tabular}{|c|c|c|c|c|c|}
\hline & \multicolumn{2}{|c|}{ Micrite-dominated oncoids } & \multicolumn{2}{|c|}{ Bacinella-Lithocodium oncoids } \\
\hline & & type 1 & type 2 & type 3 & type 4 \\
\hline \multirow{3}{*}{ 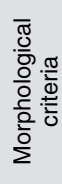 } & Prevailing size & few millimeters & few $\mathrm{mm}$ to $1 \mathrm{~cm}$ & few $\mathrm{cm}$ to $5 \mathrm{~cm}$ & few $\mathrm{mm}$ to $10 \mathrm{~cm}$ \\
\hline & $\begin{array}{l}\text { Shape and } \\
\text { surface }\end{array}$ & $\begin{array}{l}\text { elliptical to spherical } \\
\text { smooth }\end{array}$ & $\begin{array}{l}\text { elliptical } \\
\text { smooth }\end{array}$ & $\begin{array}{l}\text { elliptical } \\
\text { lobate }\end{array}$ & $\begin{array}{l}\text { elliptical } \\
\text { lobate }\end{array}$ \\
\hline & Nucleus & \multicolumn{2}{|c|}{ bioclastic or lithoclastic nucleus } & $\begin{array}{l}\text { bioclasts } \\
\text { or without nucleus }\end{array}$ & no nucleus recognizable \\
\hline \multirow{4}{*}{ 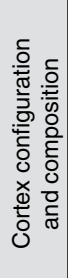 } & Lamination type & $\begin{array}{l}\text { concentric and continuous but } \\
\text { barely visible }\end{array}$ & irregular and truncated & rarely continuous & no lamination \\
\hline & Microfabric & $\begin{array}{l}\text { micritic laminations } \\
\text { or homogeneous }\end{array}$ & $\begin{array}{l}\text { micritic laminations and } \\
\text { organism-bearing laminations }\end{array}$ & $\begin{array}{l}\text { organism-bearing laminations } \\
\text { and few micritic laminations }\end{array}$ & microbial meshwork \\
\hline & Bioclasts & rare & \multicolumn{2}{|c|}{ common bioclasts } & rare \\
\hline & Microencrusters & no fauna associated & serpulid worms, Bullopora & $\begin{array}{l}\text { abundant mici } \\
\text { Bacinella, } L\end{array}$ & $\begin{array}{l}\text { crusters: } \\
\text { codium }\end{array}$ \\
\hline \multirow{2}{*}{ 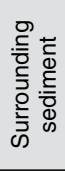 } & Classification & mudstone - wackestone & $\begin{array}{l}\text { packstone and locally } \\
\text { wackestone }\end{array}$ & \multicolumn{2}{|c|}{ mudstone - wackestone and locally packstone } \\
\hline & $\begin{array}{l}\text { Associated } \\
\text { fauna and } \\
\text { grains }\end{array}$ & \multicolumn{2}{|c|}{ mainly benthic foraminifera, peloids, and ooids } & $\begin{array}{c}\text { brachiopods, commonly } \\
\text { Mohlerina basiliensis, bivalves }\end{array}$ & $\begin{array}{l}\text { echinoderms, commonly } \\
\text { Mohlerina basiliensis }\end{array}$ \\
\hline \multirow{4}{*}{ 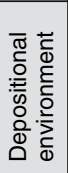 } & Relative energy & moderate and intermittent & high and intermittent & low and intermittent & very low \\
\hline & Bathymetry & \multicolumn{4}{|c|}{ subtidal } \\
\hline & Sedimentation rate & \multicolumn{4}{|c|}{ low } \\
\hline & Environment & protected lagoon & \multicolumn{3}{|c|}{ fully marine lagoon } \\
\hline
\end{tabular}

Fig. 11 Classification of the oncoids encountered in the Hauptmumienbank Member. Morphological criteria, cortex configuration and composition, surrounding sediment, and depositional environmental conditions are indicated

transgressive deposits of elementary sequence 1.3. Around and after the maximum flooding of this elementary sequence, types 3 and 4 oncoids appear. In the two last elementary sequences, type 3 oncoids dominate and type 2 oncoids reappear. Small-scale SB 2 is marked by miliolid foraminifera and type 3 oncoid rudstones. Within the elementary sequences of Vorbourg, no particular trend is observed. However, in the Voyeboeuf and Savagnières sections (Fig. 13), some elementary sequences display the same evolution as the small-scale sequence of Vorbourg. Elementary sequence 1.5 in Savagnières presents two beds, interpreted, respectively, as transgressive and highstand deposits. The transgressive bed can be subdivided into bioclastic wackestone with normal-marine fauna and oncoid-rich wackestone-floatstone. The maximum flooding is marked by types 3 and 4 oncoid mudstone to floatstone. The highstand deposit is dominated by peloidal and bioclastic wackestone. The small-scale sequence boundary is placed at the base of a serpulid bioherm with peloids and oysters. The next elementary sequence 2.1 has a lowstand deposit rich in peloids, serpulids, oysters, textulariid foraminifera, and a few type 2 oncoids. The transgressive surface is positioned at the base of an ooid-peloid-bioclastic wackestone-packstone, corresponding to abandoned bars. In Voyeboeuf, elementary sequence 1.5 is composed of ostracode and textulariid foraminifer mudstones (Fig. 13). The highstand deposit of this elementary sequence consists of clays with coal debris, detrital quartz, and serpulids, indicating relatively proximal and semi-restricted conditions and two thin wavy limestone beds composed of ostracode and foraminifer mudstone. The small-scale sequence boundary is placed at $6.6 \mathrm{~m}$ in a clayrich level. The transgressive deposit consists of foraminifer mudstone with some type 1 oncoids. The maximum flooding is placed around thin wavy beds surrounded by marls. The highstand deposit is made of a massive bed, which is rich in types 3 and 4 oncoids and benthic foraminifera at the base. In its upper part, type 3 oncoids and foraminifera (textulariid and miliolid) dominate. The next sequence boundary SB 2.2 is marked by peloid and foraminifer (miliolid and less textulariid) wackestone rich in detrital quartz. In this lowstand deposit, some type 2 oncoids are observed.

This study on the spatial and stratigraphic distribution of oncoids in lagoonal deposits shows that types 1 and 2 oncoids have both a similar distribution and preferentially form around the sequence boundaries and during transgressive conditions of elementary and small-scale sequences, indicating that enough energy was furnished to roll the particles (Figs. 12, 14). Types 3 and 4 oncoids have an inverse occurrence because they mainly occur around small-scale and elementary maximum-flooding periods and in highstand deposits, characterizing periods of low-energy and increase of Bacinella-Lithocodium growth (Figs. 12, 14). 
Oncoid distribution

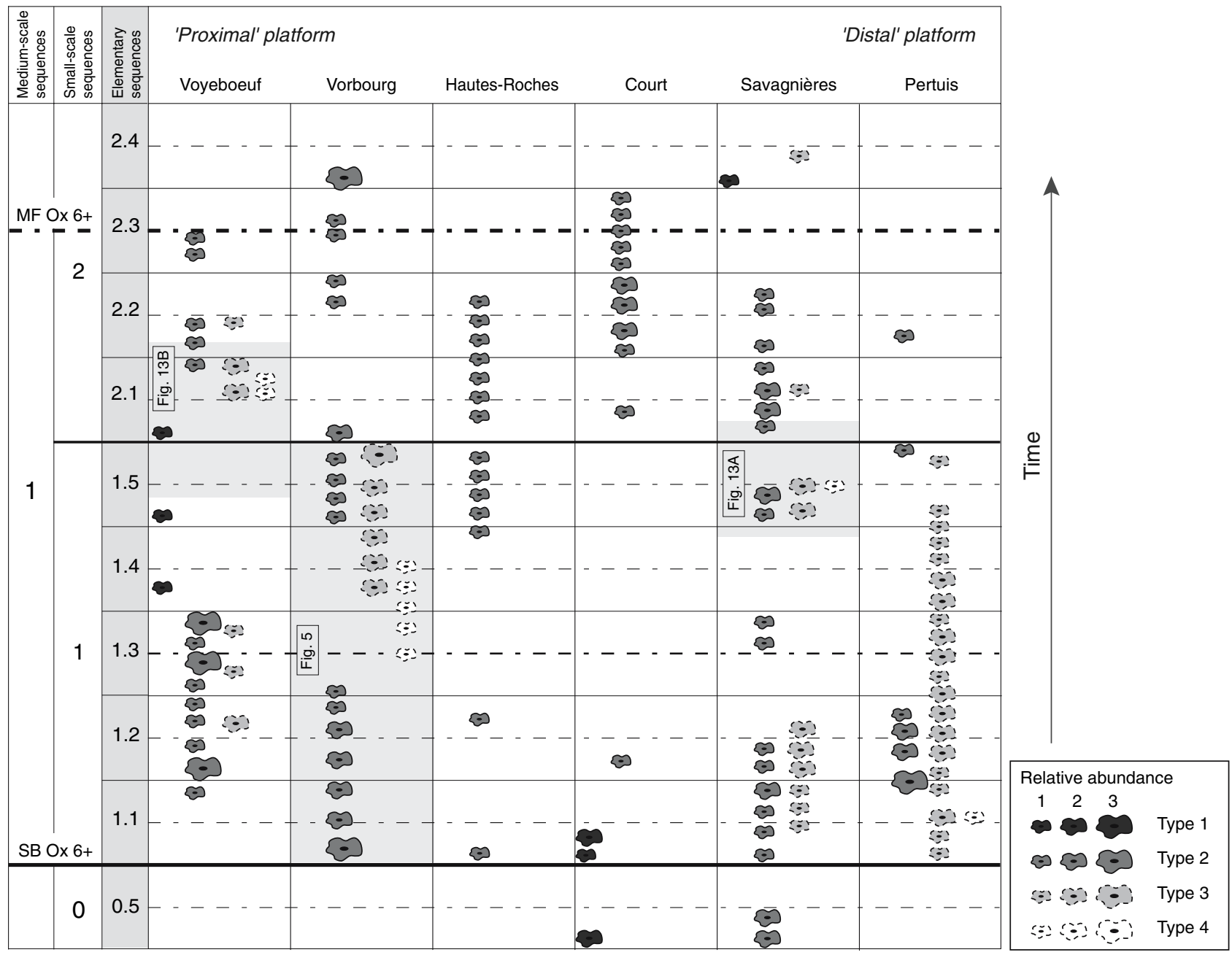

Fig. 12 Distribution of oncoid types in the elementary sequences within the transgressive deposits of the Ox 6+ medium-scale sequence for the six studied sections. Sections are arranged from "proximal" to

\section{Controlling factors}

Oncoid growth and distribution are mainly controlled by sea level and climate (Figs. 14, 15). The main direct environmental parameters are water energy, water depth, trophic level, and accumulation rate. Their influence is recognized in the stratigraphic and spatial distribution of oncoids in large-scale to elementary sequences as well as in the oncoid surface morphology, the biotic composition of the oncoid cortex, and the encasing sediment.

\section{Water energy and water depth}

The oncoid-rich facies of the Hauptmumienbank Member appears at the beginning of a second-order sea-level rise, covers the entire medium-scale Ox $6+$ sequence and then disappears above the third-order SB Ox 7 (Fig. 1). This stratigraphic distribution points to a link with changes of rel- "distal" platform. Relative abundance ( 1 present, 2 common, 3 abundant) for each oncoid type is estimated from thin section analysis. Intervals detailed in Figs. 5, 13 are shaded

ative sea level. Sea-level fluctuations play an important role in opening and closing shallow lagoons behind barrier systems and thus strongly modify environmental factors (e.g., water energy, oxygenation, salinity, temperature, sediment transport). The specific evolution of oncoid types within small-scale and elementary sequences confirms the link also to high-frequency sea-level fluctuations. The sub-spherical types 1 and 2 oncoids, mainly resulting from sediment trapping by micro-organisms, preferentially occur around sequence boundaries and in transgressive deposits where higher energy conditions predominated in relatively shallow water (Fig. 14). This implies that these particles needed energy to be overturned and rolled. On the other hand, the lobate types 3 and 4 oncoids are characteristic of low-energy environments where microbial meshwork had time to grow. Types 3 and 4 oncoids are concentrated around maximum floodings and in highstand deposits where low-energy conditions existed in relatively deep water but still in the photic 


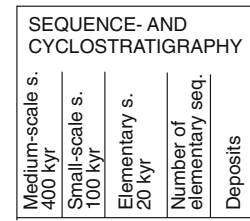

(A) Savagnières
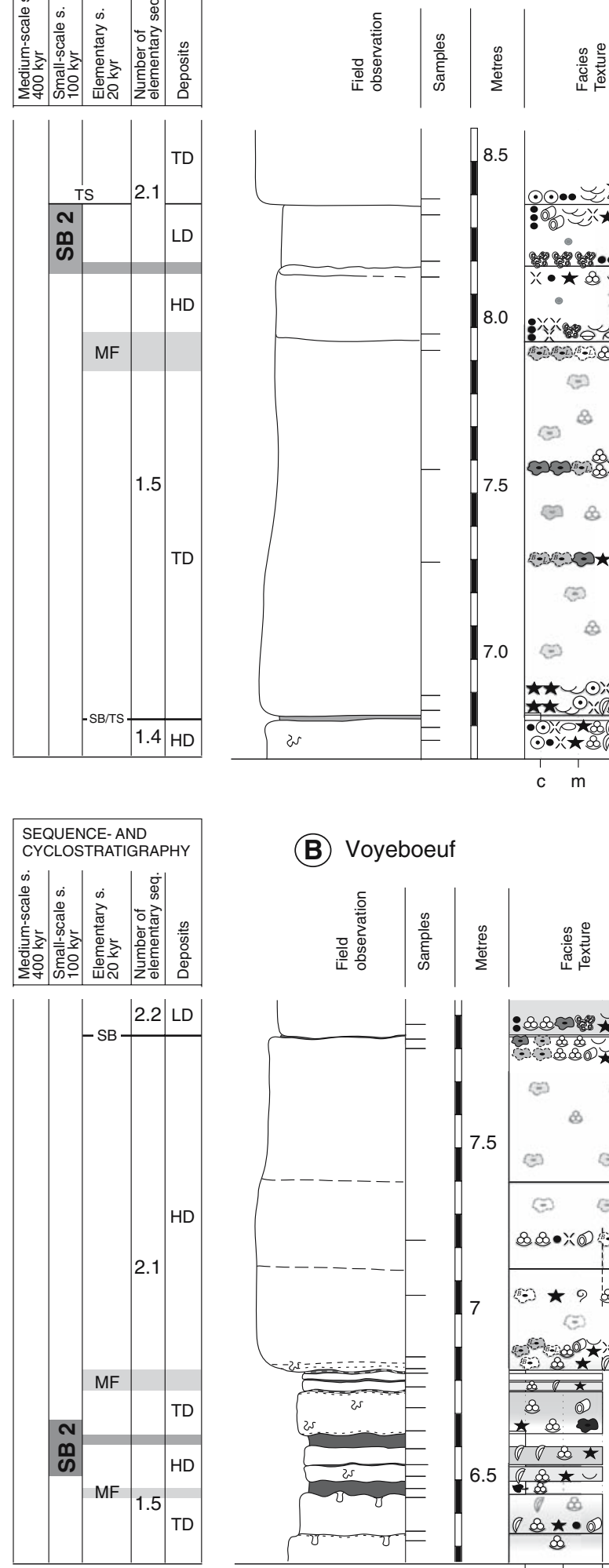

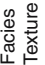

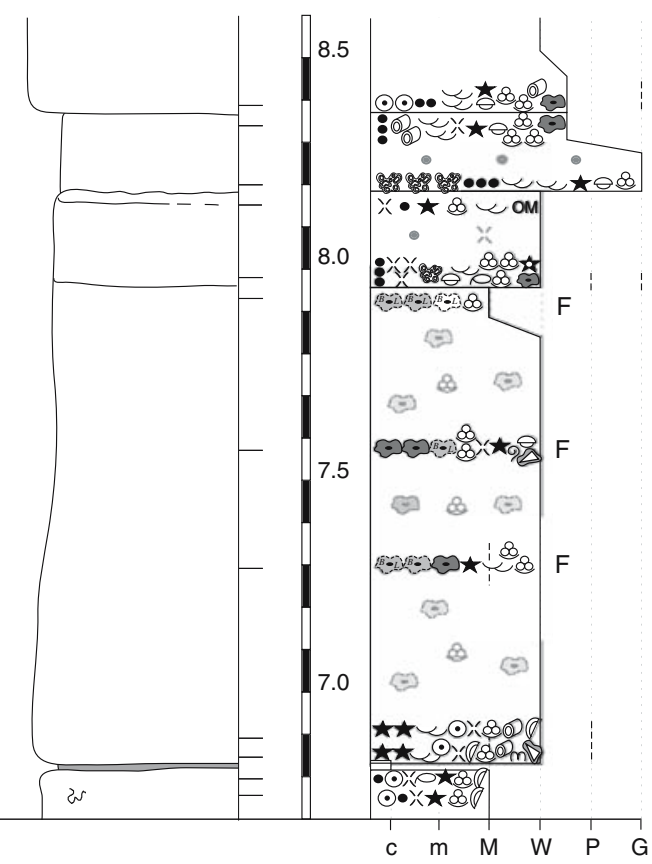

(B) Voyeboeuf
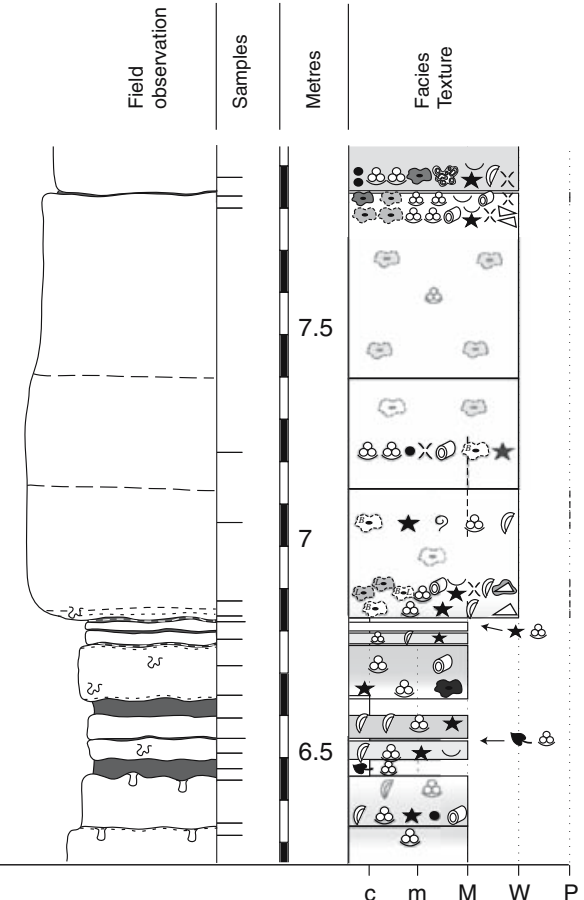
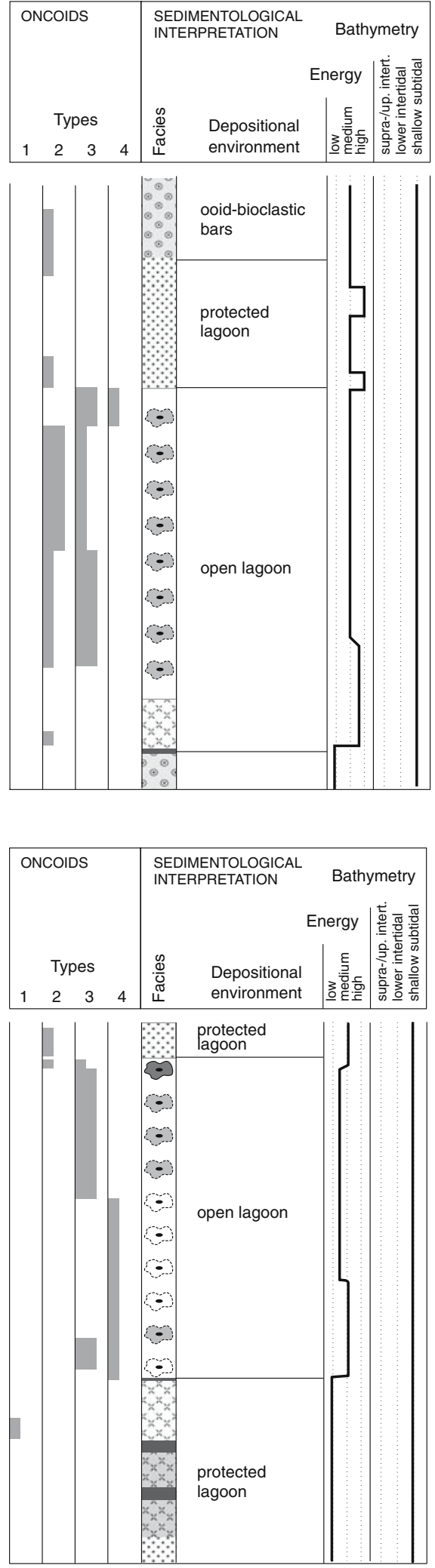

Fig. 13 Selected elementary sequences of the Savagnières and Voyeboeuf sections around small-scale sequence boundary SB 2, showing the distribution of the four oncoid types, facies types, the palaeoenvi- ronmental interpretation, and the sequence-stratigraphic framework. For discussion, refer to text. Legend of symbols in Fig. 4 


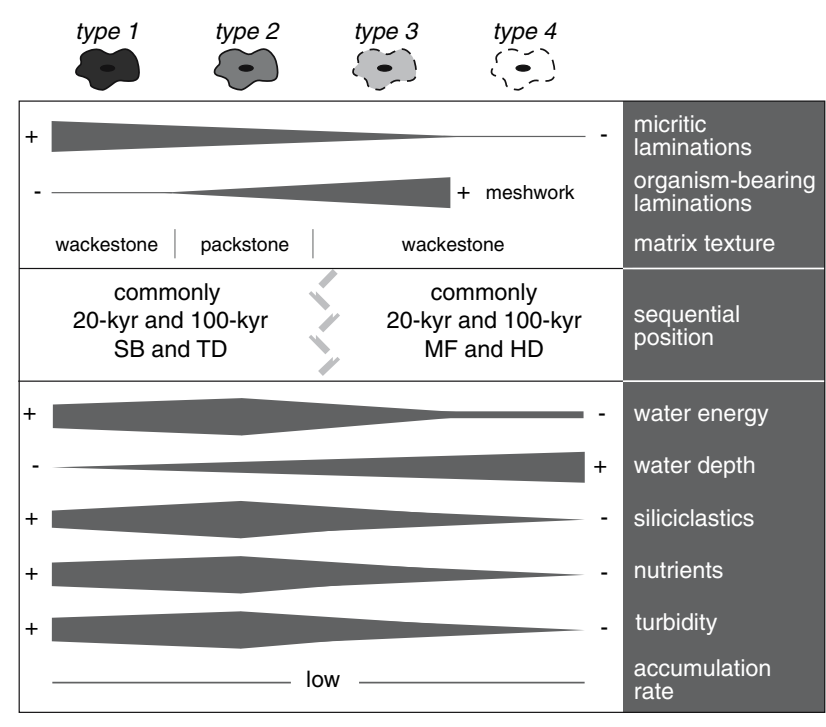

Fig. 14 Oncoid types, sequential position, and main controlling factors. For discussion refer to text

zone (Fig. 14). Consequently, the oncoid surface morphologies indicate the intensity of rolling on the sea floor and thus the degree of wave or current energy and, indirectly, the water depth. The biotic composition and diversity in the oncoid cortex and the encasing sediment (e.g., Dunham texture, faunal association) provides additional information on water energy and water depth.

Platform morphology was created by differential subsidence of tectonic blocks and by differential sediment accumulation (e.g., Pittet 1996; Allenbach 2001; Hug 2003; Wetzel et al. 2003). The already existing highs and depressions were further accentuated by the increase of carbonate production in reefs and on ooid shoals. Oncoids were preferentially accumulated in depressions. Hallock (1988) also suggests that the point sources of terrigenous input and the platform morphology increase the spatial heterogeneity of nutrient distribution and thus trophic level. Consequently, variable platform morphology was partly responsible for the patchy distribution of oncoid-rich facies and oncoid types (Figs. 7, 15).

In the studied sections, some oncoid-rich beds are capped by ooid bars, which may have been controlled by autocyclic processes (Fig. 7). On shallow carbonate platforms, such processes are inherent and involve lateral migration of sediment bodies (Ginsburg 1971; Pratt and James 1986; Strasser 1991). Consequently, autocyclic processes were superimposed on the orbitally controlled sealevel fluctuations and represented an additional factor in oncoid growth and distribution.

\section{Accumulation rate}

Carbonate accumulation rates mainly depend of the local carbonate production but can also be modified by carbonate transport (supply or exportation). On the Swiss Jura platform, the accumulation rate of oncoid-rich lagoons has been estimated at around $0.11 \mathrm{~mm} /$ year (after sediment decompaction), which is low in comparison to modern lagoonal environments (Strasser and Samankassou 2003; Strasser and Védrine 2007).

Microbial crusts commonly grow slowly. Their occurrence is considered to be diagnostic for low background

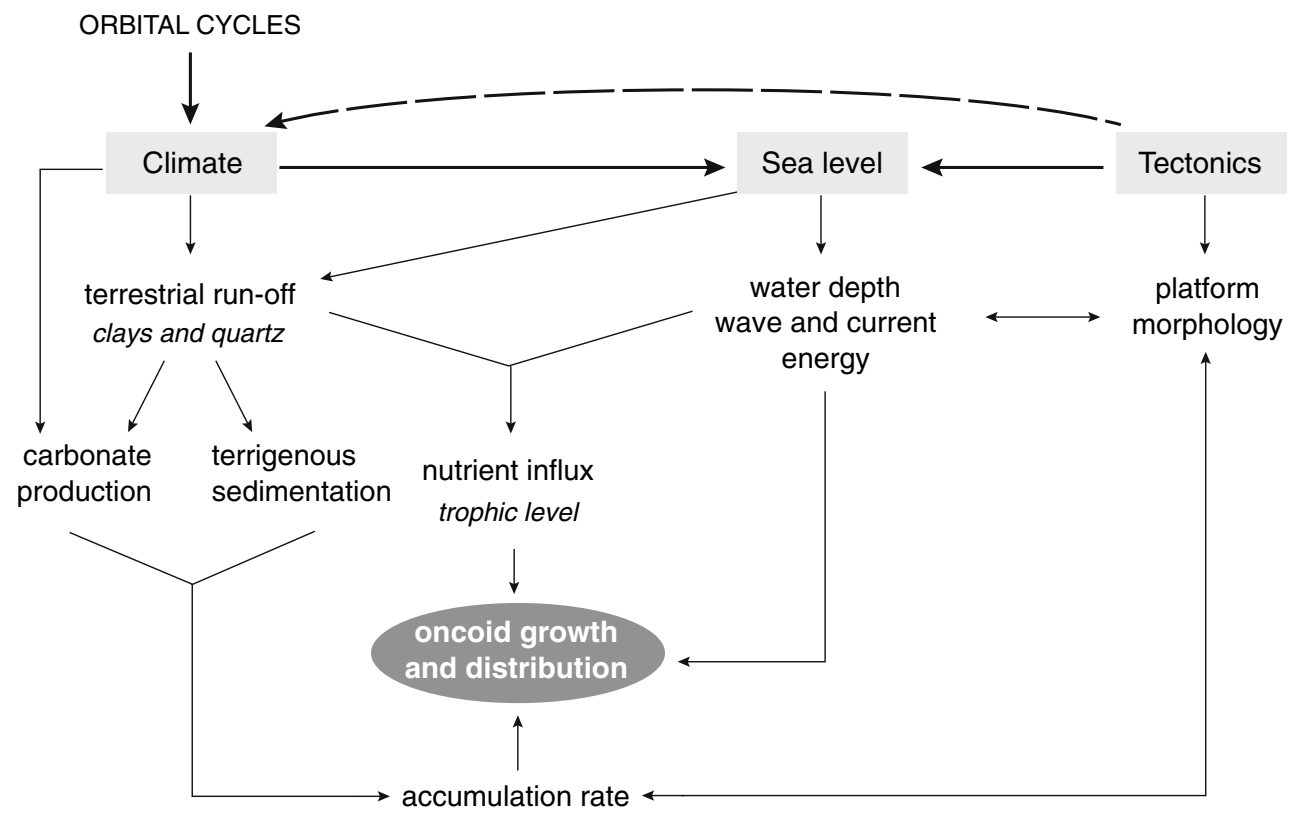

Fig. 15 Interrelated factors controlling oncoid growth and distribution. For discussion refer to text 
sedimentation rates (Leinfelder et al. 1993). Similar requirements are probable for oncoids, which are partly or totally composed of the same microencrusters such as the Bacinella-Lithocodium association (e.g., Peryt 1983; Dupraz 1999).

\section{Trophic level}

The deposition of the massive Hauptmumienbank limestones on top of the Röschenz marls points to a general trend toward a lower input of siliciclastics and a higher carbonate productivity. Decreasing terrigenous input may have been related to a change to less humid climate conditions in the hinterland.

In the studied sections, oncoids occur abundantly in limestones and occasionally in marls. In the limestone beds, types 1-4 oncoids are present whereas in the marly intervals only type 2 oncoids are found. The biotic composition of the oncoid cortex and the encasing sediment imply specific trophic conditions (Fig. 11). Type 2 oncoids enclose serpulids and textulariid foraminifera, which tolerate mesotrophic to eutrophic conditions (e.g., Brasier 1995; Fugagnoli 2004). The concomitant growth of type 2 oncoids with such organisms and their occurrence in clay-rich environments suggest that they were adapted to low water transparency and potentially high trophic levels. Type 1 oncoids are rare in the studied sections and found in limestone beds. They show affinity with type 2 oncoids: the scarcity of associated fauna probably indicates mesotrophic or eutrophic conditions, making life difficult for carbonate producing organisms. Types 3 and 4 oncoids are constituted of light-dependent microencrusters (i.e., Bacinella and Lithocodium) implying clear water and oligotrophic conditions (Dupraz and Strasser 1999; Fig. 14). They occur in the massive limestone beds, which formed when siliciclastic and nutrient input was reduced. Growing under water on the sediment surface, oncoids thus monitor water transparency and trophic level, which are both driven by the episodic influx of terrigenous sediment (quartz, clays, organic matter, and nutrients) onto the shallow carbonate platform.

\section{Conclusions}

Oncoid formation and distribution were studied in the Hauptmumienbank Member (Late Oxfordian, Swiss Jura) within a precise time framework obtained by sequence and cyclostratigraphy. Four types of oncoids are defined based on surface morphology, configuration and composition of the cortex, and the encasing sediment. Type 1 is sub-elliptical, micritic, and has a homogeneous cortex; Type 2 is elliptical, smooth, and displays micritic laminations with serpulid worm tubes and Bullopora; Type 3 is elliptical, lobate, and shows alternating laminae of Bacinella-Lithocodium and micrite; Type 4 is lobate and consists mainly of a Bacinella-Lithocodium meshwork.

The elementary and small-scale depositional sequences, in which the oncoids occur, are related to the 20 -kyr orbital precession cycle and to the 100-kyr eccentricity cycle, respectively. Thus a high-resolution time framework for the study oncoid formation and distribution is given. The stratigraphic and spatial distribution of oncoids in the six studied sections shows that each oncoid type can be attributed to a specific depositional environment. Type 1 oncoids characterize moderate-energy conditions in protected lagoons; Type 2 oncoids are related to higher energy conditions in open lagoons; Types 3 and 4 oncoids dominate in low to very low-energy settings in open lagoons. Moreover, oncoid distribution is linked to relative sea-level changes. Micrite-dominated oncoids (types 1 and 2) are preferentially found around sequence boundaries and in transgressive deposits, whereas oncoids containing Bacinella-Lithocodium (types 3 and 4) are found rather around maximum floodings and in highstand deposits. This implies that changes in water energy and water depth were direct controlling factors. The heterogeneous oncoid distribution through space and time implies that the variable morphology of the Swiss Jura platform was also a controlling factor. As for coral reefs and microbialites, oncoid formation required relatively low sediment accumulation rates. Humidity changes in the hinterland controlled terrigenous run-off (clays and nutrients) and thus carbonate production. Types 1 and 2 oncoids grew under mesotrophic to eutrophic conditions, while types 3 and 4 oncoids flourished in oligotrophic waters. This study demonstrates that oncoids are valuable proxies for high-resolution palaeoenvironmental and palaeoecological studies.

Acknowledgments We gratefully acknowledge the financial support of the Swiss National Science Foundation (grant no. 20-67736.05). We also thank Rüdiger Henrich and an anonymous reviewer for their constructive remarks.

\section{References}

Allenbach R (2001) Synsedimentary tectonics in an epicontinental sea: a new interpretation of the Oxfordian basins of northern Switzerland. Eclogae Geol Helv 94:265-287

Berger A, Loutre MF, Dehant V (1989) Astronomical frequencies for pre-Quaternary palaeoclimate studies. Terra Nova 1:474-479

Bolliger W, Burri P (1967) Versuch einer Zeitkorrelation zwischen Plattformcarbonaten und tiefermarinen Sedimenten mit Hilfe von Quarz-Feldspat-Schüttungen (mittlerer Malm des Schweizer Jura). Eclogae Geol Helv 60:491-507

Bolliger W, Burri P (1970) Sedimentologie von Schelf-Karbonaten und Beckenablagerungen im Oxfordien des zentralen Schweizer Jura. Beitr Geol Karte Schweiz NF 140:96 
Brasier MD (1995) Fossil indicators of nutrient level 1: eutrophication and climate. Marine palaeoenvironmental analysis from fossils. Geol Soc Lond Spec Publ 83:113-132

Cherchi A, Schroeder R (2006) Remarks on the systematic position of Lithocodium Elliott, a problematic microorganism from the Mesozoic carbonate platforms of the Tethyan realm. Facies 52:435-440

Dahanayake K (1977) Classification of oncoids from the Upper Jurassic carbonates of the French Jura. Sediment Geol 18:337-353

Dahanayake K (1978) Sequential position and environmental significance of different types of oncoids. Sediment Geol 20:301-316

Dahanayake K (1983) Depositional environments of some Upper Jurassic oncoids. In: Peryt TM (ed) Coated grains. Springer, Berlin Heidelberg New York, pp 377-385

Dercourt J, Ricou LE, Vrielynck B (eds) (1993) Atlas: Tethys palaeoenvironmental maps. CCGM, Paris

Dupraz C (1999) Paléontologie, paléoécologie et évolution des faciès récifaux de l'Oxfordien moyen-supérieur (Jura suisse et français). GeoFocus 2, Univ. Fribourg, 200 pp

Dupraz C, Strasser A (1999) Microbialites and micro-encrusters in shallow coral bioherms (Middle to Late Oxfordian, Swiss Jura Mountains). Facies 40:101-130

Elliott GF (1956) Further records of fossil calcareous algae from the Middle East. Micropaleontology 2:327-334

Flügel E (2004) Microfacies of carbonate rocks. Analysis, interpretation and application. Springer, Berlin Heidelberg New York, 976 pp

Frakes LA, Francis JE, Syktus JI (1992) Climate modes of the Phanerozoic. Cambridge University Press, Cambridge, $274 \mathrm{pp}$

Fugagnoli A (2004) Trophic regimes of benthic foraminiferal assemblages in Lower Jurassic shallow water carbonates from northeastern Italy (Calcari Grigi, Trento Platform, Venetian Prealps). Palaeogeogr Palaeoclimatol Palaeoecol 205:111-130

Ginsburg RN (1971) Landward movement of carbonate mud: new model for regressive cycles in carbonates (abstract). AAPG Bull 55:340

Gradstein FM, Agterberg FP, Ogg JG, Hardenbol J, van Veen P, Thierry J, Huang Z (1995) A Triassic, Jurassic and Cretaceous time scale. In: Berggren WA, Kent DV, Aubry MP, Hardenbol J (eds) Geochronology, time scales and global stratigraphic correlation. SEPM Spec Publ 54:95-126

Gsponer P (1999) Étude géologique et sédimentologique de l'anticlinal du Chasseral dans la région de la Heutte. Unpublished diploma thesis, Univ. Fribourg, $107 \mathrm{pp}$

Gygi RA (1969) Zur Stratigraphie der Oxford-Stufe (oberes Jura-System) der Nordschweiz und des süddeutschen Grenzgebietes. Beitr Geol Karte Schweiz NF 136:123

Gygi RA (1982) Sedimentation und Fazies des Späten Jura imzentralen Juragebirge. Jber Mitt Oberrhein Geol Ver NF 64:17-28

Gygi RA (1986) Eustatic sea-level changes of the Oxfordian (Late Jurassic) and their effect documented in sediments and fossil assemblages of an epicontinental sea. Eclogae Geol Helv 79:455491

Gygi RA (1992) Structure, pattern of distribution and paleobathymetry of late Jurassic microbialites (stromatolites and oncoids) in northern Switzerland. Eclogae Geol Helv 85:799-824

Gygi RA (1995) Datierung von Seichtwassersedimenten des Späten Jura in der Nordwestschweiz mit Ammoniten. Eclogae Geol Helv 88:1-58

Gygi RA (2000a) Annotated index of lithostratigraphic units currently used in the Upper Jurassic of northern Switzerland. Eclogae Geol Helv 93:125-146

Gygi RA (2000b) Integrated stratigraphy of the Oxfordian and Kimmeridgian (Late Jurassic) in northern Switzerland and adjacent southern Germany. Mém. de l'Académie Suisse des Sciences Naturelles, vol 104, 152 pp
Gygi RA, Persoz F (1986) Mineralostratigraphy, litho- and biostratigraphy combined in correlation of the Oxfordian (Late Jurassic) formations of the Swiss Jura range. Eclogae Geol Helv 79:385454

Hallock P (1988) The role of nutrient availability in bioerosion: consequences to carbonate build-ups. Palaeogeogr Palaeoclimatol Palaeoecol 63:275-291

Hardenbol J, Thierry J, Farely MB, Jacquin T, De Graciansky PC, Vail PR (1998) Jurassic chronostratigraphy. In: De Graciansky PC, Hardenbol J, Jacquin T, Vail PR, Farley MB (eds) Sequence stratigraphy of European basins. SEPM Spec Publ 60 (chart)

Heim A (1916) Monographie der Churfrsten-Mattstock-Gruppe (3 Teil). Beitr Geol Karte Schweiz NF 20:369-573

Helm C, Schülke I (1998) A coral-microbialite patch reef from the Late Jurassic (Florigemma bank, Oxfordian) of NW Germany (Süntel Mountains). Facies 39:75-104

Hug W (2003) Sequenzielle Faziesentwicklung der Karbonatplattform des Schweizer Jura im Späten Oxford und frühesten Kimmeridge. GeoFocus 7, Univ. Fribourg, 155 pp

Immenhauser A, Hillgärtner H, van Betum E (2005) Microbial-foraminiferal episodes in the Early Aptian of the southern Tethyan margin: ecological significance and possible relation to oceanic anoxic event 1a. Sedimentology 52:77-99

Jordan P (1999) Géologie de la région de Montoz (Jura Bernois) avec analyse séquentielle de deux profils de l'Oxfordien moyen et supérieur. Unpublished diploma thesis, Univ. Fribourg, 104 pp

Leinfelder RR, Nose M, Schmid DU, Werner W (1993) Microbial crusts of the Late Jurassic: composition, palaeoecological significance and importance in reef construction. Facies 29:195-230

Mohler W (1938) Mikropaläontologische Untersuchungen in dernordschweizerischen Jura Formation. Abh Schweiz Pal Ges 60:1-53

Olivier N, Carpentier C, Martin-Garin B, Lathuilière B, Gaillard C, Ferry S, Hantzpergue P, Geister J (2004) Coral-microbialite reefs in pure carbonate versus mixed carbonate-siliciclastic depositional environments: the example of the Pagny-sur-Meuse section (Upper Jurassic, northeastern France). Facies 50:229-255

Peryt TM (1981) Phanerozoic oncoids-an overview. Facies 4:197-214

Peryt TM (1983) Oncoids: a comment to recent developments. In: Peryt TM (ed) Coated grains. Springer, Berlin Heidelberg New York, pp 273-275

Pittet B (1996) Contrôles climatiques, eustatiques et tectoniques sur des systèmes mixtes carbonates-siliciclastiques de plate-forme: exemples de l'Oxfordien (Jura suisse, Normandie, Espagne). Unpublished PhD Thesis, Univ. Fribourg, 258 pp

Plunkett JM (1997) Early diagenesis of shallow platform carbonates in the Oxfordian of the Swiss Jura Mountains. Unpublished PhD Thesis, Univ. Fribourg, 157 pp

Pratt BR, James NP (1986) The St. George Group (lower Ordovician) of western Newfoundland: tidal flat island model for carbonate sedimentation in epeiric seas. Sedimentology 33:313-343

Pümpin VF (1965) Riffsedimentologische Untersuchungen im Rauracien von St. Ursanne und Umgebung (Zentraler Schweizer Jura). Eclogae Geol HeIv 58:799-876

Radoicic R (1959) Some problematic microfossils from the Dinarian Cretaceous. Bull Serv Géol Géophys RP Serbie 17:87-92

Rameil N (2005) Carbonate sedimentology, sequence stratigraphy, and cyclostratigraphy of the Tithonian in the Swiss and French Jura Mountains. GeoFocus 13 Univ. Fribourg, 246 pp

Rollier L (1898) Deuxième supplément à la description géologique de la partie jurassienne de la feuille VII. Matér Carte géol Suisse NS $8,206 \mathrm{pp}$

Samankassou E, Strasser A, Di Gioia E, Rauber G, Dupraz C (2003) High-resolution record of lateral variations on a shallow carbonate platform (Upper Oxfordian, Swiss Jura Mountains). Eclogae Geol Helv 96:425-440 
Schlagintweit F, Ebli O (1999) New results on microfacies, biostratigraphy and sedimentology of Late Jurassic-Early Cretaceous platform carbonates of the Northern Calcareous Alps, Part I: Tressenstein limestone, Plassen Formation. Abh Geol 56:379418

Schlagintweit F, Gawlick HJ, Lein R (2005) Mikropaläontologie und Biostratigraphie der Plassen Karbonatplattform der Typlokaität (Ober-Jura bis Unter-Kreide, Salzkammergut, Österreich). J Alpine Geol 47:11-102

Schmid DU (1996) Marine Mikrobolithe und Mikroinkrustierer aus dem Oberjura. Profil 9:101-251

Schmid DU, Leinfelder RR (1996) The Jurassic Lithocodium aggregatum-Troglotella incrustans foraminiferal consortium. Palaeontology 39:21-52

Shiraishi F, Kano A (2004) Composition and spatial distribution of microencrusters and microbial crusts in upper Jurassic-lowermost Cretaceous reef limestone (Torinosu limestone, southwest Japan). Facies 50:217-227

Steinmann G (1880) Die Mumien des Hauptrogensteins. N Jahrb Min Geol Paläont 1:151-154

Strasser A (1991) Lagoonal-peritidal sequences in carbonate environments: autocyclic and allocyclic processes. In: Einsele G, Ricken W, Seilacher A (eds) Cycles and events in stratigraphy. Springer, Berlin Heidelberg New York, pp 709-721

Strasser A, Samankassou E (2003) Carbonate sedimentation rates today and in the past: Holocene of Florida Bay, Bahamas, and Bermuda versus Upper Jurassic and Lower Cretaceous of the Jura Mountains (Switzerland and France). Geol Croat 56:1-18
Strasser A, Védrine S (2007) Controls on facies mosaics of carbonate platforms: a case study from the Oxfordian of the Swiss Jura. Intern Assoc Sediment Spec Publ (in press)

Strasser A, Pittet B, Hillgärtner H, Pasquier JB (1999) Depositional sequences in shallow carbonate-dominated sedimentary systems: concepts for a high-resolution analysis. Sediment Geol 128:201221

Strasser A, Hillgärtner H, Hug W, Pittet B (2000) Third-order depositional sequences resulting from Milankovitch cycles. Terra Nova 12:303-311

Thiry M (1982) Les kaolinites des argiles de Provins: géologie et cristallinité. Bull Minér 105:521-526

Thierry J et al (2000) Early Kimmeridgian. In: Dercourt J, Gaetani M et al (eds) Atlas peri-Tethys, palaeogeographical maps, map 10. CCGM/CGMW, Paris

Wetzel A, Allenbach R, Allia V (2003) Reactivated basement structures affecting the sedimentary facies in a tectonically "quiescent" epicontinental basin: an example from NW Switzerland. Sediment Geol 157:153-172

Ziegler PA (1956) Geologische Beschreibung des Blattes Courtelary (Berner Jura) und zur Stratigraphie des Sequanien im zentralen Schweizer Jura. Beitr Geol Karte Schweiz NF 102:101

Ziegler MA (1962) Beiträge zur Kenntnis des unteren Malm im zentralen Schweizer Jura. Unpublished PhD Thesis, Univ. Zürich, p 51

Ziegler PA (1988) Evolution of the Arctic-North Atlantic and the Western Tethys. Am Assoc Petrol Geol Mem 43, 198 pp 